\title{
NO HORIZONTE HÁ UMA COSMOPOLÍTICA INDÍGENA DIANTE DO \\ ANTROPOCENO OU DO CAPITALOCENO?
}

\author{
Paula Grazielle Viana dos Reis ${ }^{1}$
}

Etnologia indígena com cinema e fotos: aproximações ${ }^{2}$

No horizonte deste presente artigo vislumbra-se algo da cosmopolítica amazônica (Viveiros de Castro, 2008) feita pelos índios diante do primeiro e do atual Antropoceno a partir de histórias e mitos e, especialmente, a partir de um momento etnográfico (Strathern, 2014) feito entre os índios Apyãwa (Tapirapé) durante a festarito-sazonal Iraxao voltada para os espíritos dos índios Iny (Karajá, Javaé e Ixybiòwa). Sendo que muitos desses encontros etnográficos foram mediados por relações entretecidas com as imagens fixas e em movimento (vice-versa) (Caixeta de Queiroz, 2008). Especificamente, com o uso e compartilhamento de fotos e filmes documentários e etnográficos antigos e atuais feitos no século XX e XXI. Ou seja, os filmes, as fotografias e as fotos ${ }^{3}$ criam os encontros. Todavia, o foco deste artigo, que tem como tema a cosmopolítica amazônica, resultou de uma antropologia compartilhada com os índios Apyãwa (Tapirapé) e Iny (Karajá, Javaé e Ixybiòwa) durante o tempo das chuvas, sobremaneira, durante a festa Iraxao quando foi possível, não somente ver, dialogar e formular perguntas com o uso do cinema e das fotos impressas e digitais, como também, produzir fotografias (EDWARDS, 2016) e filmes etnográficos e documentários e receber filmes (France, 2000) e fotos (EDWARDS, 2016) feitos pelo

\footnotetext{
${ }^{1}$ Universidade Federal de Minas Gerais, Brasil. Email: paulaviananp@gmail.com ORCID id: https://orcid.org/0000-0002-5251-034X

${ }^{2}$ Agradeço especialmente aos índios Apyãwa e Iny pelo acolhimento tanto em Tapi'itãwa (T.I. Urubu Branco), como na Universidade Federal de Goiás (UFG).

${ }^{3}$ Elizabeth Edwards (2016) em Rastreando a fotografia discutiu as fronteiras existentes entre o que concerne uma fotografia entendida como meio e ao que tange as fotos como objetos materiais, consequentemente essas diferenças agiram na elaboração do meu momento etnográfico e expressos neste artigo, uma vez que levei em consideração ambos os sentidos.
} 
professor e antropólogo Koria Yrywaxa durante as festas-ritos-sazonais realizadas pelos índios Apyãwa.

Começo por indagar-me sobre o início dessa etnografia com os índios Apyãwa (Tapirapé), para tanto, elenco aqui um momento de imersão significativo, que pode ser descrito da seguinte maneira: quando vi novamente algumas fotos feitas entre os índios Apyãwa em 2013. Estas fotos foram tiradas durante as festas que ocorreram no tempo da seca no território Tapi'itãwa situada na Terra Indígena Urubu Branco. Pois, foi neste momento de imersão ao ver essas fotos que consegui formular a seguinte pergunta: tais fotos estariam dentro de uma caixa de pandora ${ }^{4}$ ? Sim e não. Aquelas fotos ${ }^{5}$ estiveram dentro de uma caixa de sapato e as tirei de dentro da caixa poucas vezes, mas das poucas vezes que fiz isso, as vi com um enorme encantamento. De fato, não pensei em um lugar mais adequado para guardá-las. É importante dizer que essas 13 fotos, impressas em papel fotográfico, algumas coloridas e outras em preto e branco, quase todas com as mesmas dimensões $(21 \times 15 \mathrm{~cm})$ constituíram num presente do cineasta e fotógrafo Vandimar Marques Damas. Tais fotos compõem seu acervo pessoal e foram feitas entre os índios Apyãwa (Tapirapé) durante seu trabalho de campo em Tapi'itãwa para sua pesquisa de doutoramento (Damas, 2016a).

Depois disso, passaram-se alguns anos quando li um pequeno artigo " $O$ camponês e a fotografia" (2006), escrito por Pierre e Marie-Claire Bourdieu e ali estava posto uma reflexão sobre a recente inserção da fotografia na vida dos camponeses de Béarn, nos inícios de 1960, por meio da análise dos usos sociais e os sentidos das fotografias e da prática fotográfica entre esses camponeses. Nada demais, para uma “civilização da imagem" como diz Boris Kossoy (2001: 30), a não ser pelo fato que nessa afirmativa o clichê está embutido. Quando Pierre e Marie-Claire Bourdieu (2006) mencionam sobre as relações entre a fotografia e os camponeses captaram algo que muitas vezes são postas de lado em uma reflexão que quer pensar a fotografia como objeto material ou narrativa ou instrumento de pesquisa. Neste sentido, Vilém Flusser (2011) contribui para desvelar algo da caixa de pandora (Latour, 2001) ao propor os

\footnotetext{
${ }^{4}$ Certamente é uma alusão ao livro "A esperança de Pandora" escrito por Bruno Latour (2001) no que tange os aspectos ontológicos correlacionados ao conhecimento científico e seu corpo cosmopolítico.

${ }^{5}$ Quando retornei ao território Tapi'itãwa em 2018, entreguei essas fotos para o professor Xawaromy Arakae, que as guardou no acervo da escola indígena EIE Tapi'itãwa.
} 
termos "imagens técnicas" (Flusser, 2011: 5). No caso, para pensar a foto não apenas em torno das visualidades, ou seja, o que "as fotos demonstram em si mesmas" (Strathern, 2014: 211) e sim a partir da máquina em si. E se as fotos, as fotografias e os aparelhos não estão dados entre os diversos povos e etnias existentes nessa Terra/terra, há o que se pensar com a contribuição dessas teorias citadas sobre essas máquinas, bem como suas histórias seja ao que concerne à prática fotográfica seja ao que tange as relações engendradas entre os humanos por meio delas e quais são os sentidos disso.

Assim, além de visualizar as fotos produzidas durante a etnografia desse cineasta e fotógrafo entre os índios Apyãwa - não só as fotos impressas e digitais presentes em seu acervo pessoal -, mas também, as fotos que elegeu para constar em suas publicações (Damas, 2016a). Pouco a pouco, fui tecendo alguns entrecruzamentos com outras fotos feitas pelos antropólogos/fotógrafos entre os índios Tapirapé, como as publicadas tanto por Herbert Baldus em "Tapirapé: Tribo Tupí no Brasil Central” (1970) quanto por Charles Wagley em "Welcome of Tears: the Tapirape indians of Central Brazil" ([1977] 1988). Uma vez que, esses antropólogos clássicos usaram as fotografias como instrumento de pesquisa através da coleta de dados durante o trabalho de campo ${ }^{6}$, mas também como objeto material e como narrativa seja ao publicá-las como resultados de suas pesquisas em artigos (Baldus, 1949) e na composição de suas etnografias (Baldus, 1970; Wagley [1977] 1988). Seja ao usar essas fotos como ilustração de suas teorias.

De modo geral, essas fotos antigas passaram a gerar alguns incômodos, os quais abaixo vou precisar. Cabe dizer, agora, que esse presente que recebi de Vandimar Marques se materializou em um impulso (Wagner, 2010: 40-41) em também tecer uma etnografia entre os índios Tapirapé. Porém, quando pude ir à Terra Indígena Urubu Branco - em janeiro de 2017 - levei apenas algumas fotos digitais antigas feitas pelos frades e padres da Missão Dominicana, pelos antropólogos Herbert Baldus e Charles Wagley. Acabei não conversando com os índios Tapirapé sobre essas fotos, embora tenha percebido, durante a festa Iraxao como os índios Tapirapé apreciam posar para fotos. Pois, chegaram perto da gente e nos pediram para que fizéssemos algumas delas e que também gostariam de recebê-las impressas. Daí, eu me lembrei do presente (as

\footnotetext{
6 Atualmente, muitas dessas fotos compõem as coleções etnográficas como imagens de arquivo (Lindeperg, 2015) e preservadas pelo LISA-USP e pela Universidade da Flórida.
} 
fotos impressas) e da importância de fomentar diálogos por meio do compartilhamento de fotos e filmes, o que foi realizado num segundo momento de imersão no território Tapi'itãwa, durante o tempo das chuvas (em dezembro de 2018), com os diálogos mediados pelo cinema e pelas fotos antigas e atuais (Viana dos Reis e Caixeta de Queiroz, 2018).

Os incômodos, então, dizem respeito à ontologia das imagens fotográficas e fílmicas (Bazin, 1983) antigas e atuais como instauradoras de dúvidas para quem as vê. O que elas dizem? Como eu e os Tapirapé as vemos? Sobretudo, ao visualizarmos esse material fotográfico e fílmico antigo e atual, em que medida, tais diálogos e compartilhamentos (France, 2000) contribuem para traduzir, nos termos de Manuela Carneiro da Cunha (2009) o conhecimento tradicional e nos termos de Eduardo Viveiros de Castro (2008) a cosmopolítica amazônica vivenciada pelos índios Apyãwa (Tapirapé)? De uma forma não tão direta e (t)a(n)genciando tais incômodos e questões, que estão postos sobre um fundo ético, político, estético, ontológico e epistemológico, pouco a pouco, tentarei apontá-los desde o ponto em que me encontro que é multissituado conforme a imagem conceitual ${ }^{7}$ escrita por Ulf Hannerz (2003) quando nos reporta a condução de sua etnografia multissituada.

Neste sentido, o foco desse artigo é a festa Iraxao que ocorre no território tradicional Tapirapé como já foi fotografado, pela primeira vez, pelo antropólogo Charles Wagley ([1977] 1988), no tempo das chuvas, durante seu trabalho de campo entre os anos de 1939 e 1940.

\footnotetext{
${ }^{7}$ A noção de imagem conceitual é discutida por Eduardo Viveiros de Castro (2001) em "a propriedade do conceito" e melhor desenvolvida numa publicação recentemente traduzida para a língua portuguesa em Metafisicas canibais (Viveiros de Castro, 2015).
} 


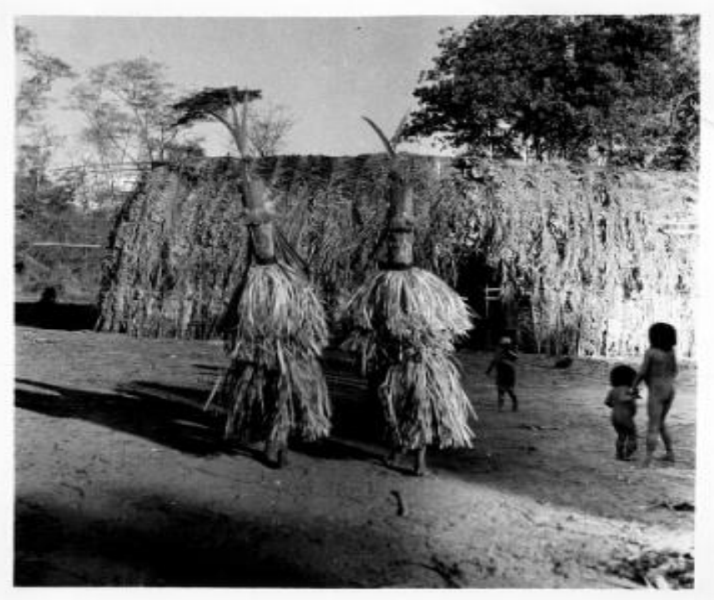

Fotógrafo: Charles Wagley. 1939-1940. Foto presente na coleção etnográfica Latino-americana/ Charles Wagley da Universidade da Flórida.

Com o uso desta foto (acima) caracterizada como uma imagem de arquivo (Lindeperg, 2015) tirada por Charles Wagley da festa Iraxao, é para demonstrar que percorri alguns caminhos que me distanciaram, de certa maneira, do método proposto por Etienne Samain (1995) de pensar, apenas, as fotos e suas legendas, bem como o uso e a composição das mesmas nas publicações de etnografias clássicas. Digo, de certa maneira, porque esse método está imbricado com a antropologia visual feita por Samain (1995) a partir da etnografia clássica de B. Malinowski (1978). Sendo que, Samain (1995) explicita para quem quiser seguir esse método posto para a antropologia visual, que não há soluções prontas e para quem adentrá-lo poderá encontrar situações inesperadas e imprevisíveis que poderão até transformar o próprio método e por isso mesmo, como no nosso caso, interessantes para o engendramento de relações entre etnologia e história e/ou para essa teoria etnográfica (Goldman, 2006). Foi com a análise primeiro do lugar das fotos nos livros escritos pelos antropólogos Baldus (1970) e Wagley ([1977]1988) que desencadeou mais outros momentos de imersão com as imagens de arquivos (Lindeperg, 2015) que compõem as coleções etnográficas desses dois antropólogos presente no ciberespaço: acervo presente no website do Laboratório de Imagem e do Som vinculado ao Departamento de Antropologia da Universidade de São Paulo e no website da Universidade da Flórida, especificamente, na University of Florida Digital Collections - The Charles Wagley Papers Digital Collection.

Com tais momentos de imersão no ciberespaço, ou seja, de ver e estudar tais documentos digitais presentes nestas coleções etnográficas dos antropólogos Charles 
Wagley e Herbert Baldus foi possível o desvelamento de algo que não estava posto em suas publicações. Com isto consegui, então, constatar que dentre essas fotos antigas publicadas e as imagens de arquivo (Lindeperg, 2015) existentes nestas coleções etnográficas acerca dos índios Tapirapé, apenas, Charles Wagley ([1977] 1988) registrou por meio das câmeras fotográficas durante o tempo das chuvas a festa-ritosazonal Iraxao voltada para os espíritos dos mortos dos animais e dos índios Iny. Tal festa é voltada para axepaanog (alegrar) com os espíritos (axigas), que se autodenominam Iny. Os índios Iny (Karajá, Javaé e Ixybiòwa) pertencem ao "tronco linguístico Macro-Jê" (Toral, 1992; Rodrigues, 2008; Ferreira Lima, 2011; Nunes, 2016; 2018) e ficaram historicamente mais conhecidos pelas etnônimos Karajá e Javaé.

Conforme o calendário dos índios Apyãwa (Tapirapé) denominado “calendário do tempo" (Tapirapé, 2007; Tapirapé, 2009a), a realização da festa-rito-sazonal denominada Iraxao, que se volta para os axigas ${ }^{8}$ só pode ocorrer se a casa dos homens (Takãra) estiver construída no terreiro (takope) do território tradicional. Isto porque, as relações entre os índios Tapirapé e Karajá são intensificadas dentro da Takãra (casas, casa dos homens, casa cerimonial, casa de tradições, casa do porcão, casa dos espíritos, casa tradicional) ${ }^{9}$ para axepaanog (festejar e alegrar), quando todos que participam da festa Iraxao consomem cauim para alegrar com os espíritos para que nenhum deles façam algo de ruim com ninguém, como me disse Yrywaxa.

Durante o tempo das chuvas, fotografei e filmei, pouco a pouco, a fabricação dos artefatos, a feitura das pinturas nos corpos e seus retoques. Bem como, pude filmar e fotografar alguns momentos do par de máscaras-xamãs Iraxao e a fabricação do cauim de mandioca e amendoim ${ }^{10}$. Bem como, pude realizar um momento de compartilhamento em Tapi'itãwa com a projeção dos dez filmes etnográficos feitos por

\footnotetext{
8 Traduzidos para a língua portuguesa por Koria Yrywaxa por meio de conversações (diálogos e entrevistas) estabelecidas via WhatsApp em 2019 e 2020.

9 Elenquei as traduções que já vislumbrei sobre a Takãra ao consultar e ler algumas referências bibliográficas e fílmicas referentes ao povo indígena Tapirapé (Baldus, 1970, Wagley, 1988, Rocha, 1997; Andrade, 2010; Paula, 2012; Severino-Filho, 2015; Damas, 2016a; Viana dos Reis; Marques Damas, 2018; Arawani Tapirapé, 2018).

${ }^{10}$ Tais filmes de pesquisa e fotografias foram feitos no escopo do curso de doutoramento em antropologia social por meio do projeto de tese Maracás e máscaras: parentesco e xamanismo entre os Tapirapé durante as variações sazonais com o plano de trabalho Antropologia compartilhada entre os índios Apyãwa (Tapirapé): cinema e etnografia (Viana dos Reis e Caixeta de Queiroz, 2018).
} 
Harald Schultz (1959-1960) entre os índios Iny (Karajá, Javaé e Ixybiòwa) e do filme documentário Traços Tapirapé (Damas, 2016b) ${ }^{11}$ feito durante a festa Iraxao, que ocorreu em janeiro 2014. Com esses filmes e fotos do passado e do presente, somados com a ida à Tapi'itawa, onde comecei a fazer fotografias e filmes etnográficos, conforme André Leroi-Gourhan, especificamente, filmes de pesquisa (Leroi-Gourhan, 1948) entre os índios Apyãwa e Iny. Sem deixar de mencionar também o estudo das imagens de arquivo e das fotos antigas, localizados a partir das etnografias clássicas (Samain, 1995) de Baldus (1970) e Wagley ([1977] 1988), mas também presente em algumas coleções etnográficas, acervos e arquivos. Então, com todas estas imagens técnicas reunidas e vistas para este momento etnográfico entre os índios Apyãwa e Iny são as responsáveis para uma possível tradução da festa Iraxao como algo da cosmopolítica amazônica.

\section{Imagens padrões acerca dos índios Tapirapé presentes nos livros}

Posso destacar, aqui, que mesmo dentro da etnologia indígena várias pesquisas de maiores fôlegos acabaram por criar uma(s) dada(s) imagem padrão ou imagens padrões ao buscar abarcar a diversidade dos povos indígenas situados nas terras baixas do continente sul-americano. Neste sentido, ao aprofundar o estudo, sobremaneira, entre os índios Apyãwa (Tapirapé) o intuito, então, é buscar traçar uma imagem que não seja clichê e/ou etnocêntrica e/ou racista e que traduza algo da cosmopolítica amazônica feita entre os índios Apyãwa. Isso não é simples. Uma vez que, não tenho como não lidar com as imagens conceituais e técnicas presentes nas pesquisas antropológicos (e até mesmo arqueológicos) clássicas e contemporâneas.

Para tanto, esse artigo busca demonstrar algo das imagens fixas e em movimento (vice-versa) (Caixeta de Queiroz, 2008) acerca dos índios Apyãwa (Tapirapé) ao reconhecer que tanto as fotografias, as fotos e o cinema, como as versões de mitos, ditos

\footnotetext{
${ }^{11}$ Este filme compôs o $6^{\circ}$ Cine Kurumin - Festival de Cinema Indígena em Salvador, no dia 14 de julho de 2017; o $8^{\circ}$ fifer - Festival Internacional do Filme Etnográfico do Recife, conforme a programação participou da mostra competitiva, no dia 22 de novembro de 2017. Vandimar Marques Damas (2015; 2017) refletiu sobre a feitura do filme Traços Tapirapé em diversos eventos científicos e cinematográficos, como no Encontro Internacional de Antropologia Visual (EIAV) realizado pelo Gravi e Lisa da Universidade de São Paulo; no IV Congresso Latino Americano de Antropologia, que ocorreu na Cidade do México em 2015 e numa mesa temática do Pirinópolis Doc - III Festival de Documentário Brasileiro, que ocorreu em agosto de 2017. Atualmente, o vídeo Traços Tapirapé pode ser visto no vimeo: https://vimeo.com/217294858
} 
pelos índios Tapirapé presentes nas etnografias antigas e atuais revelam imagens conceituais. Sendo que isto faz parte de algumas teorias antropológicas e arqueológicas. Sem desconsiderar, que a produção recente (livros, artigos, filmes e fotos) feita pelos estudantes e professores Apyãwa (Tapirapé) também demonstram algo, especialmente, da cosmopolítica amazônica. Todavia, é preciso demonstrar que essas imagens fixas e em movimento tendo como tema a festa-rito-sazonal Iraxao revelam variações.

Neste sentido, ao ver, manejar e comparar as fotos e filmes antigos e atuais algo do conhecimento tradicional e certamente da cosmopolítica amazônica vivenciada pelos índios Apyãwa veio a baile, certamente, mais perceptível no âmbito da visualidade. Mas, inteligível enquanto histórias. É necessário dizer ainda que podem ser demonstrados com os mais variados sentidos, conforme pondera Claude Lévi-Strauss $(1982 ; 1990 ; 1993 ; 2004 ; 2012 ; 2014 ; 2017)$ e por isso, é importante demonstrar também as histórias a partir das fotos e filmes que foram feitos, atualmente, pelos próprios índios por também reverberarem a importância de se perpetuar o calendário do tempo (Tapirapé, 2007; 2009a) com o registro da festa Iraxao.

Todavia, começo pelo livro publicado na metade do século passado, que se refere a uma porção da América do Sul, cuja vegetação é definida como floresta tropical e o habitat de diversas tribos, sendo que nas suas bordas estariam os povos marginais, andinos e circum-caribenhos. Isso porque parti do "Handbook of South American Indians" (HSAI) composto de sete volumes e organizado por Julian Steward (19461959). Por mais que esses volumes não sejam frequentemente usados como fonte de pesquisa por ora, parece que algumas imagens que se originaram e estão fixadas lá nesses sete volumes emergem como pressupostos de algumas teorias antropológicas e arqueológicas. Sucintamente, a Amazônia que abriga diversos povos indígenas foi apreendida pelos teóricos do HSAI como lócus onde vivem as sociedades simples, as denominadas Tribos da Floresta Tropical. Esta classificação quer dizer que as tais tribos carecem de instituições políticas, prevalecendo um igualitarismo, conhecem a agricultura de queima e coivara e também caçam e pescam. Assim, viviam em aldeias mais permanentes, apesar de dispersas sobre o território e convergiriam mais pessoas morando juntas do que nos bandos. Tomo como ponto de partida essa imagem padrão produzida pelo HSAI, onde os índios Tapirapé, mesmo que de forma implícita, têm 
alguma coisa a ver com as críticas feitas pela antropologia a tal imagem relacionada aos ameríndios e a Amazônia.

Alguns antropólogos contribuíram com o HSAI (Steward, 1948), dentre eles cito Curt Nimuendaju, Claude Lévi-Struss, R. Lowie, Métraux, Eduardo Galvão e Charles Wagley. Todavia, a produção destes não corroborou ou pelo menos teve como efeito nuançar a imagem padrão. O que quer dizer que essa imagem, desde o início, não foi estática e totalizante. Também ocorreu uma presença minoritária no próprio Handbook, que buscou delinear outra imagem, certamente, mais complexa, como por exemplo, cito os artigos escritos por Claude Lévi-Strauss (2012), que foram organizados no livro Antropologia Estrutural.

Durante o período de produção do volume III "The tropical forest tribes" do HSAI, Eduardo Galvão e Charles Wagley (1948) já tinham realizado alguns trabalhos de campo entre os índios Tupi (Tapirapé e Tenetehara-Guajajara), sendo que foram eles que escreveram para o volume III um artigo-verbete sobre os índios Tapirapé. Se Julian Steward (1948), organizador do HSAI atribuía à descendência unilinear um papel de destaque, vendo a Amazônia ocupada por aldeias mono ou multilinhageiras, ao concentrarmos no artigo-verbete sobre os índios Tapirapé, as relações de parentesco levam em conta, por um lado, as formas de residência, no caso, uxorilocal, antecipando um debate posto por Peter Riviere (2001) sobre a vigência de classificações sociais por gradiente de distância genealógico-residencial, exprimindo um dualismo concêntrico entre o exterior e interior de cada casa (maloca residencial) para os índios caribes e demais povos da Guiana ${ }^{12}$. Neste sentido, Claude Lévi-Strauss (2012) destacou a complexidade das estruturas diametrais e concêntricas, que organizam tanto as aldeias dos índios falantes da língua Jê como também estão presentes entre os índios Tapirapé, falantes da língua Tupi. Porém, apenas, como metades cerimoniais masculinas que se subdividiam em grupos etários e habitam a Takãra (a casa dos homens ou a casa cerimonial). Logo, o lugar interdito às mulheres Apyãwa é a Takãra, a casa dos homens,

\footnotetext{
${ }^{12}$ Tânia Lima demonstra que entre os Yudjá, um povo Tupi que vive no Xingu, não é observável a indistinção entre parentesco e co-residência. “... a distância espacial não motiva a assimilação de parentes próximos aos parentes distantes, e co-residentes não são assimilados aos parentes próximos. (...) $\mathrm{E}$, embora as relações de alteridade (os primos cruzados, os que são considerados não-parentes, os amigos pertencentes a outros povos) sejam marcados de ambivalência, eu estaria inclinada a caracterizar os Yudjá mais como um povo que valoriza positivamente a alteridade do que como xenófobo (Rivière, 2001: 91). Por fim, a endogamia não serve de objeto para a elaboração de uma ficção social, como ocorre nas Guianas, nem a visão indígena sugeriria que "não existe sociedade fora da aldeia" (ibidem: 136)" (Lima, 2005: 101).
} 
lugar onde estão presente a Associação dos Pássaros (Wyrã). Este, é composto de duas metades cerimoniais, que por sua vez, cada metade se subdivide em três grupos etários.

Por muito tempo, os etnólogos tendem a tomar a aldeia ou a comunidade local como unidade de análise mais abrangente. Isto devido à necessidade de descrever sociedades praticamente desconhecidas ou por vários povos estarem reduzidos a uma só aldeia; adesão demasiado estreita às ideologias nativas ou resultado de uma posição teórico-filosófica explicitada nas obras de Pierre Clastres (Viveiros de Castro, 2011, p. 333). Porém, em “Independência e Exogamia” Clastres ([1963] 2003) buscou refletir sobre a inaplicabilidade da categoria tribo para pensar as identidades coletivas existentes na paisagem amazônica, que se caracterizam pela formação de "demos exogâmicos".

No entanto, Pierre Clastres (2003) tinha tateado com dados etnográficos de uma vasta região - as terras baixas sul-americanas em contraposição às terras altas. Mesmo assim, no artigo de 1963, não deixou de citar alguns povos indígenas que contradiziam sua posição ou que pelo menos não se enquadraram em suas comparações e se configuraram como exceções. Dentre estes, Clastres (2003) citou os índios Tapirapé, que em seus termos estavam organizados pela endogamia, configurando-se como uma exceção dos povos da Floresta Amazônica. Nota-se que, por mais que Pierre Clastres (2003) não tenha explicitado o momento histórico do genocídio e etnocídio vivenciado pelos índios Tapirapé, a endogamia foi acionada para a descrição do sistema de parentesco. Isto corrobora com as descrições feitas por Charles Wagley e Eduardo Galvão (1946) acerca das singularidades do parentesco entre os índios Tapirapé:

\footnotetext{
O sistema Tupi, descrito neste artigo, e encontrado entre os Cayuá, os Tapirapé e os Tenetehara é essencialmente o mesmo que o sistema tipo Dakota. Encontramo-lo novamente, na América do Sul, nessas três tribos ligadas à família bilateral e com a ausência de sibs unilaterais exogâmicos. As "metades" de homens e os "grupos de comer" Tapirapés não são exogâmicos e assim não são sibs; ao contrário, são sociedades cerimoniais de caça e de trabalho sem qualquer relação com as regulamentações de casamento ou de residência. (Galvão \& Wagley, 1946: 6).
}

Naquela época e em linhas gerais, a Amazônia desempenhou um papel menor no que tange à antropologia do parentesco. Porém, os índios Apyãwa, falantes da língua Tapirapé, pertencente à família linguística Tupi-guarani (Macro-Tupi), situados na Amazônia, numa região de transição do bioma cerrado para o amazônico, expressam um dualismo cerimonial com a associação dos pássaros (Wyrã), composto por homens 
subdivididos em três grupos etários. Há, portanto, entre os índios Tapirapé gradações e diferenças pautadas em gênero e idade dentro do escopo das relações de parentesco. Nota-se também que durante as festas-ritos-sazonais os corpos são feitos pelos parentes consanguíneos como a mãe, o pai ou o "irmão do pai" e a "irmã da mãe" denominados como pais classificatórios.

Todavia, em relação às metades cerimoniais masculinas existentes entre os índios Apyãwa (Tapirapé), Herbert Baldus (1967) - em “Aspectos da organização social Tapirapé: tripartição, dualidade e graus de idade" -, demonstrou o seu posicionamento sobre o uso de alguns conceitos para descrever as relações sociais perpetradas pelos índios Tapirapé. Ou seja, o uso do termo dualismo cerimonial ao invés de metades cerimoniais para definir a dinâmica da associação dos pássaros existente entre os índios Tapirapé, está em consonância com o conceito de parentesco, proposto por Claude Lévi-Strauss ([1949] 1982). Herbert Baldus (1967) quis demonstrar que ao escolher pelo uso do termo (dualidade) pretendeu se distanciar de outras noções presentes em algumas teorias antropológicas, que compreendem a noção de metades como algo correspondente às regras de casamento.

\footnotetext{
É verdade que não falei em "metades" ou "moieties" nem em "graus de idade" no sentido de grupo. Mas tenho razões para ter evitado êsses têrmos. Comumente se liga o conceito etnológico de metade à ordem matrimonial. Tanto meu mestre Richard Thurnwald (apud Baldus e Willems 1939, p. 150) como o mestre de Wagley, Ralph Linton (232), pensavam assim. Só alguns autores alargaram o sentido do termo (Baldus, 1967: 53).
}

Como formulado por Claude Lévi-Strauss (2012), a organização dualista se caracteriza por uma reciprocidade entre metades, que são ao mesmo tempo associadas e opostas. Isto não quer dizer que deverá ocorrer sempre uma compatibilidade entre terminologia do parentesco e as regras de parentesco ao que tange à residência e ao casamento. Marcela Coelho de Souza (2002), ao revisitar essa teoria, demonstrará uma série de nuances em torno do termo dualismo, ao mesmo tempo como essa questão foi sendo analisada por Lévi-Strauss. Desde a distinção entre as noções de organização dualista e dualismo, perpassando pela delimitação do dualismo como uma modalidade do princípio de reciprocidade até a compreensão da conexão entre o desequilíbrio imanente ao dualismo "simbólico" ameríndio e o desequilíbrio manifesto em suas formas institucionais (Coelho de Souza, 2002: 167). Note-se, que o dualismo para 
Claude Lévi-Strauss em "História de Lince” ([1991] 1993) expressa uma abertura para outrem, mesmo que infinitesimal, não deixa de estar em potência, abarca a história.

Marcela Coelho de Souza $(2001 ; 2002)$ ao propor repensar a noção de parentesco tão presente no pensamento antropológico e retomado de outra forma pelos etnólogos amazonistas durante a década 1970 no intuito de estabelecer comparações entre estes e os estudos dos povos de língua Jê. Ela notou, como Claude Lévi-Strauss (2012), que a aliança é o dispositivo de integração, a sociedade, e o que ela integra são grupos pré-constituídos com base na filiação. Ao comparar os Jê setentrionais com os Jê meridionais, Marcela Coelho de Souza (2001) recupera um trecho da monografia de Curt Nimuendaju entre os índios Timbira para demonstrar que os traços presentes nos corpos funcionam como sinais diacríticos. Ao cotejar o termo identificado nas diversas etnografias em relação à classificação etnopolítica ao que concerne o "nós" - a unidade étnica maior, o etnônimo - vislumbra-se o que é do universo dos humanos parentes e o que consiste a alteridade: o inimigo humano, o estrangeiro, o branco, o animal, o espírito, o artefato. Como Eduardo Viveiros de Castro (2011) demonstrou com os Araweté e para demais povos falantes do Tupi-guarani "uma topologia algo mais complexa que a tradicional relação de exclusão mútua, ou complementaridade extensiva, entre o exterior e o interior do socius" (Viveiros de Castro, 2011: 104).

Entre os índios Tapirapé, o escopo da associação dos pássaros expresso no dualismo cerimonial talvez se expresse em um dualismo em perpétuo desequilíbrio entre os atos que ocorrem na Takãra (casa dos homens) e os que ocorrem na takope (pátio da aldeia) (Tapirapé, 2017) e na floresta, também lócus das aldeias velhas. Se a construção da casa aglutina a associação, a confecção das máscaras produz o corpo, parente e pessoa com os axiga, que outrora estavam longe (na aldeia velha situada na floresta, por exemplo) e será no pátio da aldeia (takope), onde se posicionam muitas mulheres durante a festa-rito-sazonal Iraxao. As contra-efetuações das dançarinasxamãs ocorrem, sobremaneira, com o par de máscaras-xamãs. Há uma dinâmica a ser considerada, que diz dos processos de fusão e dispersão do par de máscaras-xamãs, mediada pela dança e pelo canto e concomitantemente com a fabricação dos corpos e de pessoas durante o Iraxao. Dinâmica esta, associada com as relações de afinidade e de tradição. Entre os índios Tapirapé, os cantores e dançarinos-xamãs pertencentes à associação Wyrã se relacionam com o Iraxao, sobremaneira, ao fabricar suas máscaras 
dentro da casa dos homens e depois o par de pessoas Iraxao com seus corpos enfeitados lançam mão dos maracás para marcar o ritmo da dança-canto na takope (Tapirapé, 2017).

Neste sentido, os oito diferentes cantos emitidos pelo Wyrã durante a festa Iraxao (Tapirapé, 2009b) aproximam os índios Apyãwa de outras "culturas" (Carneiro da Cunha, 2009) indígenas falantes de línguas tupi-guarani e de forma mais ampla do Macro Tupi. Como destaca Viveiros de Castro (1986),

\begin{abstract}
há uma homogeneidade linguística no Tupi no que se refere a uma memória cultural comum - no plano da mitologia, da cosmologia e do vocabulário institucional. Embora, os povos falantes dessa língua apresentem muitas diferenciações na organização social, pois há uma associação entre uma diferenciação mínima ao nível linguístico, mas uma dispersão máxima em termos geográficos e uma não menos elevada heterogeneidade no que tange a sociedade. (...) De fato, dentre todos estes povos que falam línguas tão próximas, encontramos desde pequenos bandos de caçadores nômades - Guajá, Siriono, Xetá, Aché - até as gigantescas aldeias Tupinambá históricas, com uma economia sofisticada e tecnologicamente avançada; desde sistemas sociais quase-amorfos, onde entre a família conjugal e o grupo-bando não se interpõe nenhuma estrutura intermediária, até morfologias segmentares, de tipo dualista (Tapirapé, Parintintin) ou clânico (Surui, Wayapi da Guiana). As formas de residência, as morfologias aldeãs, as terminologias de parentesco, as estruturas cerimoniais, a atitude face a guerra, a importância do xamanismo - tudo isso parece igualmente conhecer uma grande variação. Uma situação em tudo semelhante a dos dispersos e "metamórficos" Caribe (Basso, 1977: 19), que indica o caráter de "fuzzy set" de uma classificação dos traços definidores dos Caribe (Viveiros de Castro, 1986: 107).
\end{abstract}

Se a música cantada na língua Tapirapé somada com os mitos traduzem o pensamento dos índios que compõem a família linguística tupi-guarani, os índios Tapirapé dentro do horizonte tupi-guarani se diferem dos demais por conta das festasrituais bastante entrelaçadas com a sazonalidade, que só ocorrem se a Takãra (casa dos homens) estiver construída. Por sua vez, isto mais outros agenciamentos conectados com a fabricação dos artefatos como as máscaras para realização da festa Iraxao os aproximam dos índios Iny (Karajá, Javaé e Ixybiòwa). A percepção dessas semelhanças entre os índios Tapirapé (Apyãwa) com os índios Iny falantes de uma língua Jê é algo notado desde os artigos e a monografia escrita pelo antropólogo Herbert Baldus (1970).

Num certo sentido, demonstrar-traduzir, ao menos para feitura de uma teoria etnográfica (Goldman, 2006), consiste em não produzir clichês. Pois, seria fácil demais dizer que a "cultura" Tapirapé é uma reprodução da "cultura" Karajá ou Javaé ou Ixybiòwa ou vice-versa tendo como foco as visualidades postas pelas fotos e filmes antigos e atuais das festas Iraxao feita pelos índios Apyãwa e/ou pelas danças de 
máscaras Aruanã feitas pelos índios Iny. Venho percebendo isto, primeiro, a partir das diversas teorias antropológicas que situam os índios Tapirapé como exceções dentre as teorias já produzidas. Segundo, por ter compreendido que dificilmente os índios Apyãwa ou outra "cultura" indígena se enquadrariam em conceituações muitas vezes estanques, ou seja, desafiam com seu modo de vida e seu modo de pensar as muitas vezes petrificadas imagens padrões. Terceiro, cabe, aqui, delinear ou talvez destacar mais alguns desses contornos acerca dos índios Iny e Apyãwa a partir das imagens fixas e em movimento (vice-versa) (Caixeta de Queiroz, 2008).

\section{2 de janeiro de 2017: festa Iraxao}

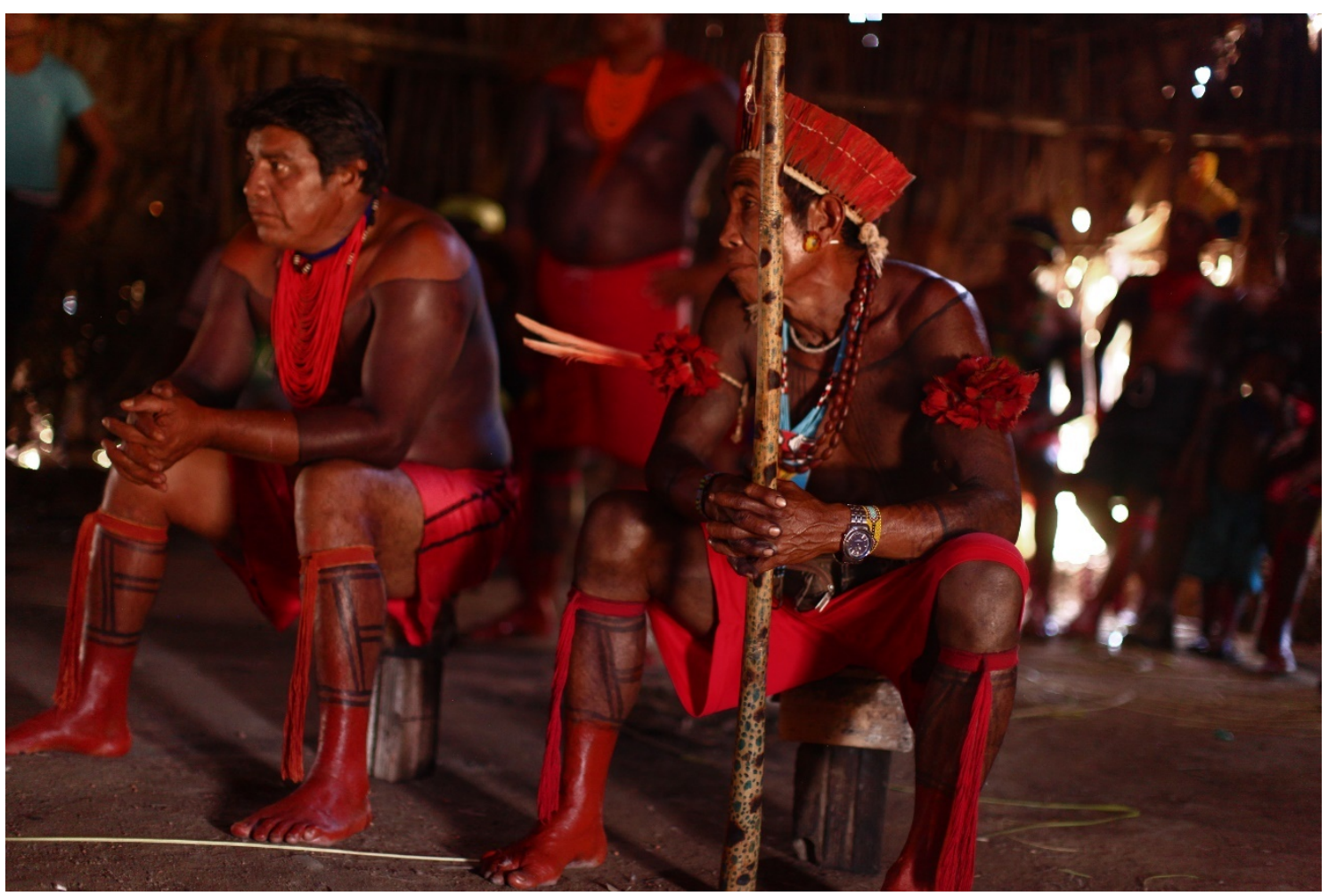

Fotógrafo: Vandimar Marques Damas. Festa-rito-sazonal Iraxao. Associação dos Pássaros (Wyrã) presente na Takãra (casa dos homens). 12 de janeiro de 2017. 


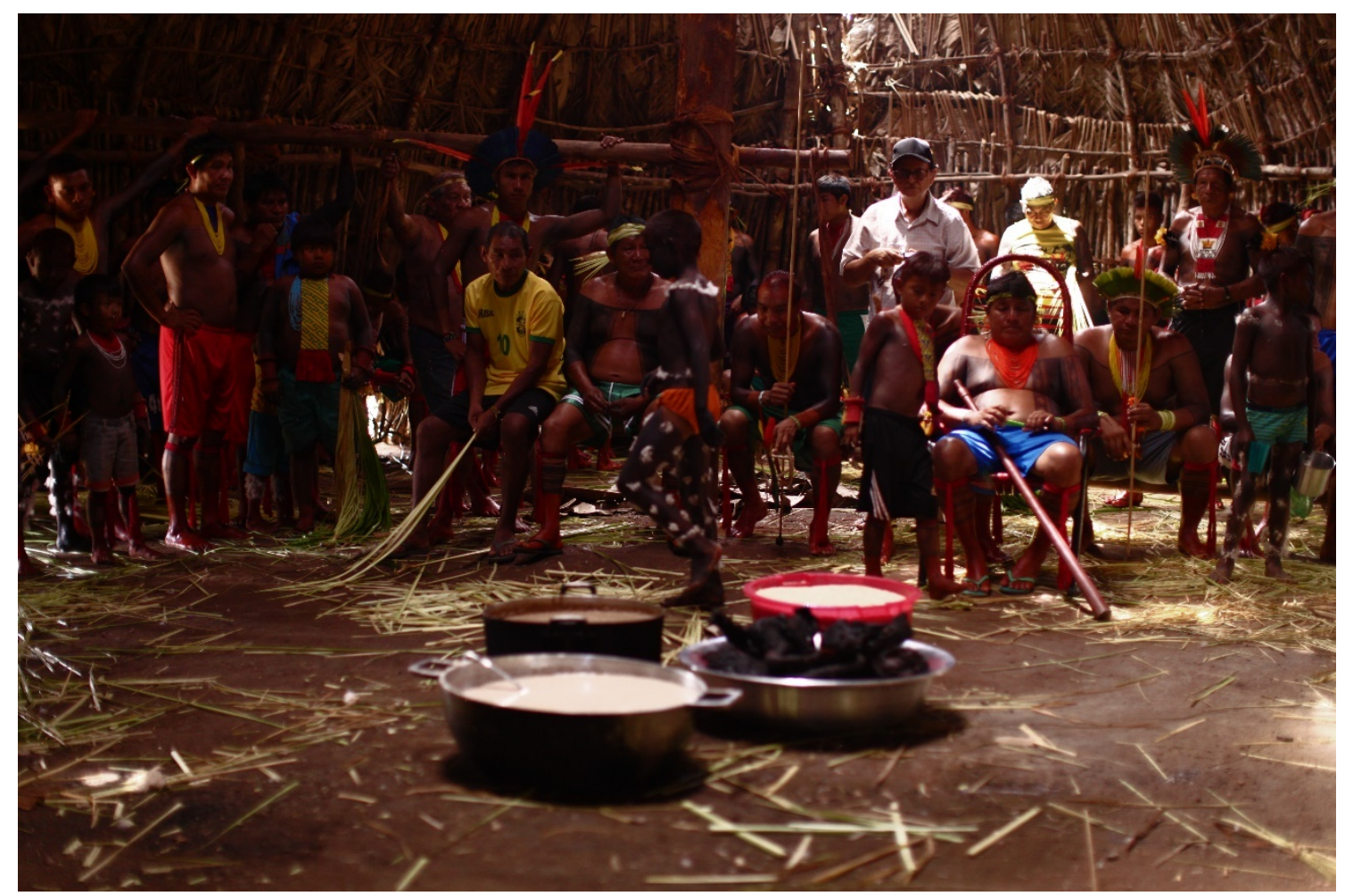

Fotógrafo: Vandimar Marques Damas. Festa-rito-sazonal Iraxao. Associação dos Pássaros (Wyrã) presente na Takãra (casa dos homens). 12 de janeiro de 2017. 


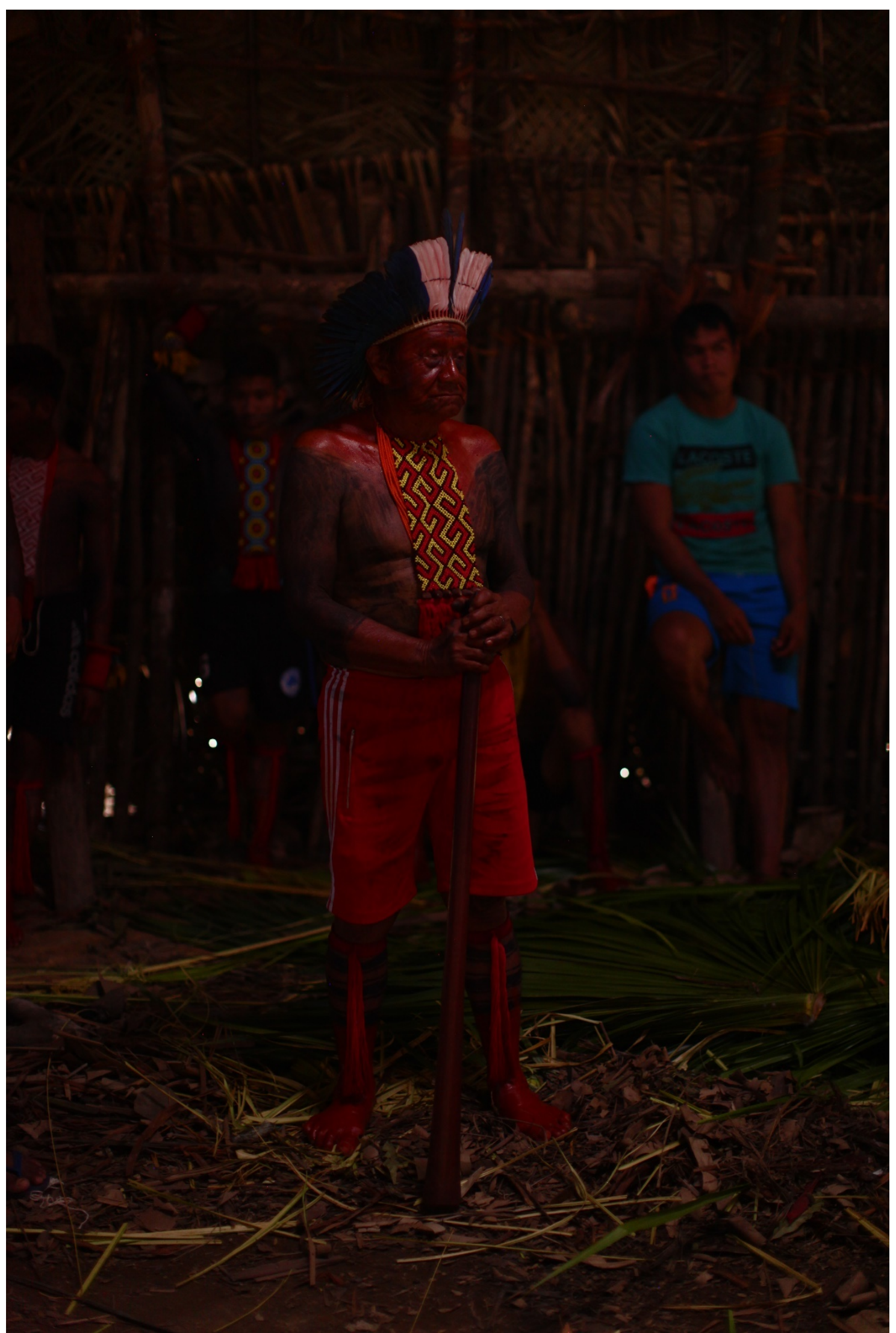

Fotógrafo: Vandimar Marques Damas. Festa-rito-sazonal Iraxao. Associação dos Pássaros (Wyrã) presente na Takãra (casa dos homens). 12 de janeiro de 2017.

Iluminuras, Porto Alegre, v. 21, n. 53, p. 425-470, agosto, 2020. 


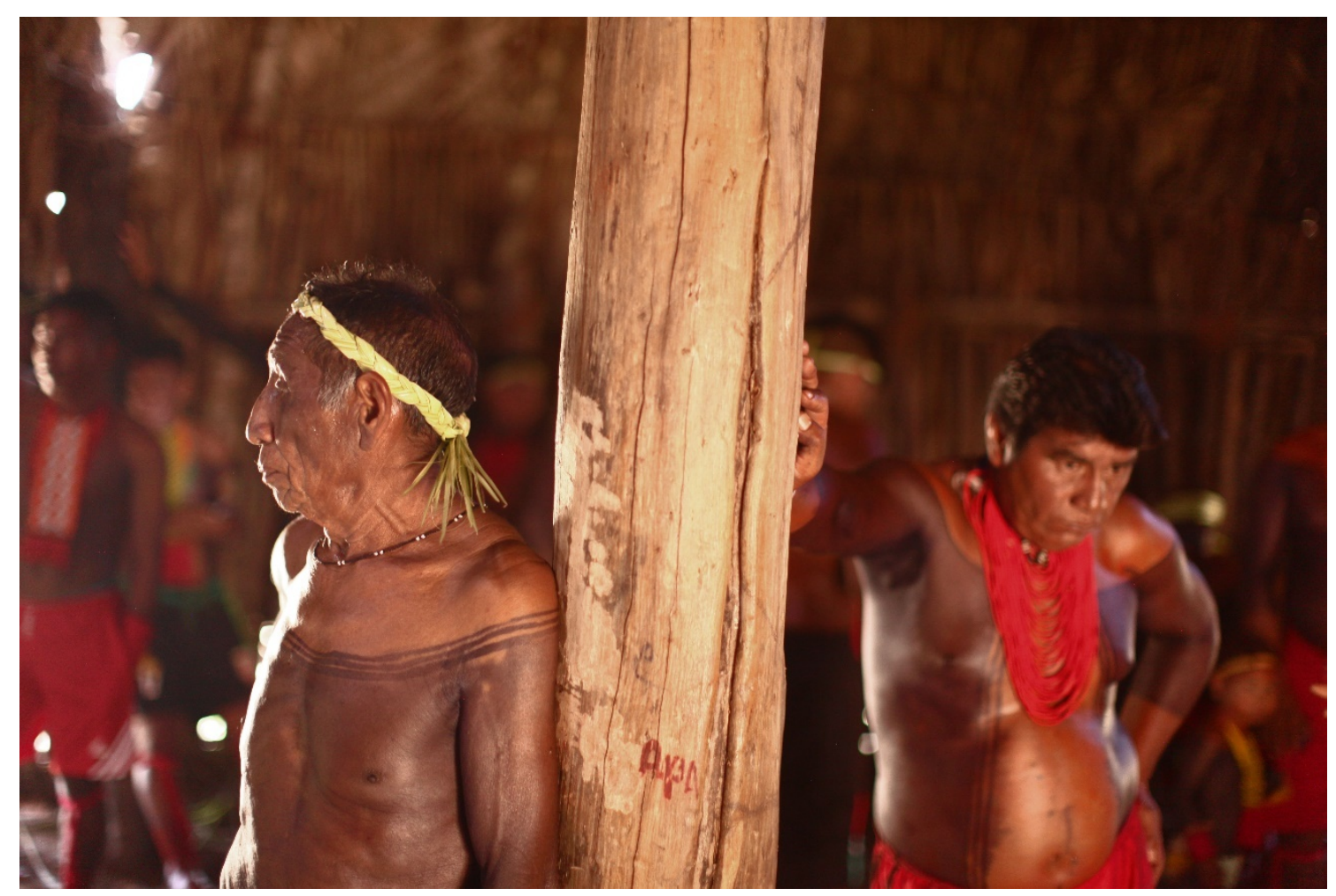

Fotógrafo: Vandimar Marques Damas. Festa-rito-sazonal Iraxao. Ancião Korako da Associação dos Pássaros (Wyrã) presente na Takãra (casa dos homens). 12 de janeiro de 2017.

\section{O atual e o primeiro Antropoceno}

Durante a festa-rito-sazonal Iraxao, que ocorreu em janeiro de 2017, nós vivenciamos entre os índios Apyãwa e Iny em Tapi'itawã uma escassez de um tipo de mandioca para fabricação da farinha puba para a preparação das bebidas como o cauim. Outra foi a de carne de caça dos porcos e caititu, que são os alimentos mais importantes da festa Iraxao. Algumas pessoas nos falaram quando as visitamos em suas casas, que as razões disso possivelmente estiveram relacionadas com o prolongamento do tempo da seca, sendo esta a responsável pela falta dessa mandioca. Muitas plantações na roça secaram e o nível das águas dos córregos diminuíram. Isto provocou a dispersão dos porcos e caititus, que costumam beber água nesses córregos que atravessam a Terra Indígena Urubu Branco. O que foi dito não nos pareceu algo banal e prosaico, uma vez que a festa Iraxao foi posta em suspenso devido a essa escassez das principais comidas e bebidas oferecidas para os seus participantes: desde ao par de máscaras-xamãs Iraxao, a associação dos pássaros (Wyrã), as mulheres Apyãwa, os índios Iny que vivem em 
Tapi'itãwa até os espíritos (axigas) dos índios Iny. Se a culinária é um importante mediador para a fabricação dos corpos e parentesco durante a realização dessa festa não é possível realizá-la sem a existência desses alimentos. Portanto, a preparação e consumo desses alimentos entre os índios Iny e Apyãwa reverberam algumas das relações sociais que podem ser traduzidas como algo da cosmopolítica amazônica.

Assim, não houve uma afluência de alimentos durante a festa Iraxao que ocorreu no tempo das chuvas de janeiro 2017 e o intuito em ressaltar isto, aqui, tem a ver com a nova era geológica que estamos vivendo, o Antropoceno. Esta nova era geológica é responsável por definir uma série de fenômenos que tem como responsáveis e causadores, sobretudo, os humanos. De uma escala micro para macro tal preocupação tem encontrado espaço nas discussões acadêmicas e produções cinematográficas. Por outro lado, vem ganhando vários contornos políticos como a aprovação de uma Política Nacional de Gestão Territorial e Ambiental de Terras Indígenas - PNGATI (Almeida e Sousa, 2015) $)^{13}$ durante o Governo Dilma Rouseff em 2012.

Há, ainda, muitas dúvidas em relação às origens dessa era: advento da agricultura? Descoberta do fogo? Revolução industrial? Uso da bomba atômica? Além de uma discussão sobre o início dessa era, o uso desse termo está envolto de debates e dissensos, não só nas universidades. Nos termos de Déborah Danowski e Eduardo Viveiros de Castro (2015) em Há mundo por vir? Ensaio sobre os medos e os fins:

[o] Antropoceno é uma época, no sentido geológico do termo, mas ele aponta para o fim da "epocalidade" enquanto tal, no que concerne a espécie. Embora tenha começado conosco, muito provavelmente terminará sem nós: o Antropoceno só deverá dar lugar a uma outra época geológica muito depois de termos desaparecido da face da terra. Nosso presente é o Antropoceno; este é o nosso tempo (Danowski $\&$ Viveiros de Castro, 2015: 16).

Para Donna Haraway (2017), o Antropoceno é mais um evento-limite do que uma época, neste momento, a terra está cheia de refugiados, humanos e não humanos, e sem refúgios”. E “[o] que importa é que narrativas contam narrativas, e que conceitos pensam conceitos. Matematicamente, visualmente e narrativamente, é importante pensar que figuras figuram figuras, que sistemas sistematizam sistemas" (Haraway, 2017: 135).

13 Conforme decreto 7747 de 05 de junho de 2012: http://www.planalto.gov.br/ccivil_03/ ato2011$\underline{\text { 2014/2012/decreto/d7747.htm }}$ 
Se este fim, a cada dia vem sendo feito e demonstrado pelas ciências atmosféricas, pela física, pela climatologia, pela geofísica, pela oceanografia, pela bioquímica, pela ecologia.

Neste sentido, foi a partir das diversas pesquisas, especialmente, feitas por parte da etnologia indígena acerca das diversas histórias veiculadas por versões de mitos ditos pelos índios acerca da criação e a destruição do mundo, que levaram pesquisadores como Déborah Danowski e Eduardo Viveiros (2015) a usarem a expressão Primeiro Antropoceno, com a intenção de traduzir o pensamento de vários povos indígenas das Américas. Com isso, voltamos não somente à cosmologia como também a algo da cosmopolítica amazônica.

O mito "é uma história do tempo em que os homens e os animais não se distinguiam" (Lévi-Strauss, 1990: 178). Os mitos são povoados de relações cuja forma, nome e comportamento misturam inextricavelmente atributos humanos e não-humanos em um contexto comum de intercomunicabilidade, ambivalência e permeabilidade. Conforme Claude Lévi-Strauss (2004: 170), entre os índios falantes da língua Jê e Tupiguarani é bastante frequente o mito sobre a origem do fogo. Eis a versão do mito de colhida entre os índios Karajá pelo antropólogo Herbert Baldus.

\footnotetext{
"Depois de um sapo ter-lhe roubado o fogo que ele negava aos homens, o demiurgo casou se com uma jovem índia. Por insistência do sogro, ele concordou em pedir ao urubu-rei os luminares celestes - estrelas, lua, sol - , que eram indispensáveis para iluminar a terra. $\mathrm{O}$ demiurgo então pediu ao urubu-rei que ensinasse aos homens, por seu intermédio, as artes da civilização. Depois disso, o pássaro (que o demiurgo havia atraído fingindo-se de morto) levantou voo.

Nesse momento, a sogra do demiurgo teve a ideia de lhe perguntar como se podia devolver a juventude aos velhos. A resposta veio de muito longe e muito alto. As árvores e alguns animais puderam ouvi-las, mas os homens, não" (Baldus, 1958: 82 apud Lévi-Strauss, 2004: 192).
}

Retorno a algumas versões dos mitos sobre a origem do fogo veiculados pelos índios falantes de línguas pertencentes a família Tupi-guarani. Tais versões dos mitos analisados por Claude Lévi-Strauss (2004) são consideradas como um grupo de transformação, que foram identificados nas seguintes Mitológicas: O cru e o Cozido (Lévi-Strauss, 2004), A origem dos modos à mesa (Lévi-Strauss, 2006) e História de Lince (Lévi-Strauss, 1993) por situar as variações sazonais em toda América tropical com as Plêiades e demonstrar as relações entre o código culinário e o astronômico. Ou 
seja, da ligação entre o mitema - uma grande unidade constitutiva - que atravessa o continente americano, a saber, a origem do fogo e suas relações com as plantas cultivadas, com as variações sazonais, com a criação e destruição do mundo.

muitas versões provêm da bacia amazônica: Tembé, Tenetehara, Tapirapé, Shipaya. Outras, do Chaco e do nordeste da Bolívia: Choroti, Tapieté, Ashluslay, Guarayo. Esse mito também é conhecido entre os Botocudo (Nimuendaju. 1946a: 111-112), e entre os vizinhos Bororo, os Bakari e os Terena. Desde a Guiana até as regiões setentrionais da América do Norte, pode ser encontrado em profusão, mas sob uma forma modificada (Lévi-Strauss, 2004: 170).

Eis a versão do mito de origem do fogo, colhida por Charles Wagley (1977 [1988]) entre os índios Tapirapé, porém presente de forma implícita n'O cru e o cozido. Nessas versões os feixes de relações que dizem do fogo de cozinha, proveniente dos urubus ou do gavião, salientam as relações de afinidade potencial ou virtual (Viveiros de Castro, 2011) dos protagonistas com as aves, dos terranos com um povo celeste, donos do fogo (Danowski \& Viveiros de Castro, 2015: 123). Esta grande unidade constitutiva diz também do fundamento da cultura humana.

\begin{abstract}
Entre os heróis míticos, foi dos mais importantes. Trouxe muitos bens para humanidade e transformou o mundo com suas artimanhas. Por exemplo, roubou o fogo do urubu-rei e o doou-o à humanidade. Antes disso, os homens sofriam com o frio e não podiam cozinhar. Para obter o fogo, Petura deitou-se, agindo como se estivesse morto. Os vermes cobriam seu corpo e o urubu-rei apareceu para se banquetear com os vermes. Primeiro ele trouxe o fogo-vermelho, depois o fogoamarelo e em seguida o fogo-preto; quando o urubu-rei estava inchado de comer vermes, Petura pegou o fogo-vermelho e correu. O urubu-rei gritou: "Traga o de volta e poderemos comer milho". Mas Petura replicou: "Não. A partir de agora você comerá apenas carne putrefata". Em consequência, hoje os urubus não comem milho (Wagley, 1988: 174).
\end{abstract}

O mito aponta para história da invenção dos bens culturais, da descoberta e obtenção do fogo de cozinha, isto é, sobre a origem da casa, do ambiente doméstico e da objetivação da cultura. O uso dos bens culturais, tais como o fogo de cozinha, atua como mediador nas relações com o cosmo - céu e terra - e o uso desses objetos juntamente com as boas maneiras mediatizam as relações entre mundos e lhes impõe um ritmo regrado e calmo. Assim, o mundo pode fluir numa certa periodicidade regular e, de certa forma, mediatizada (Lévi-Strauss, 2006: 458-459): aos urubus, conforme a perspectiva de petura-xamã, não cabe mais comer milho, apenas carne podre, pois para 
comer milho, há uma periodicidade tanto para plantá-lo e colhê-lo como para prepará-lo para alimentação e fabricação dos corpos. Isto é possível pelo conhecimento tradicional acerca das variações sazonais, o código culinário e astronômico na feitura do parentesco mediado muitas vezes por diversos objetos técnicos como os artefatos para fabricação do fogo de cozinha, a cerâmica e o os ornamentos corporais.

A versão do mito Tapirapé remete à destruição do mundo, de uma época em que, apenas o frio imperava/imperou. Dizer sobre as origens leva-nos a debates situados na fronteira entre as diversas ciências. Para a antropologia de Claude Lévi-Strauss (1982) as origens são pensadas em termos lógicos, ou seja, através dos princípios de reciprocidade, sem negligenciar a guerra, sendo esta uma troca malsucedida, como fundantes da cultura a partir do momento que ocorrem as passagens entre natureza e cultura. Daí, nos estudos dos mitos é melhor reconhecermos que estas passagens podem nos levar a constatações contraditórias (Lévi-Strauss, 2012: 295).

Ao analisar as diversas versões de mitos sobre a origem do fogo, Claude LéviStrauss (2004) aborda, dentre outras coisas, sobre as cosmopolíticas indígenas, sobre a criação e a destruição do mundo. Bem como, sobre a função que o fogo (de cozinha) desempenha ao estar como mediador entre o céu e a terra para a instauração da vida breve entre os diversos povos indígenas.

Nos mitos nota-se que as histórias narram a presença incessante do sol que podia/pode até assar a carne com o seu calor, ou seja, estado de conjunção entre o céu e a terra e o perigo iminente do mundo ficar queimado ou como aponta, haveria uma "manifestação suprema do dia" e se acontecer uma disjunção entre eles, o mundo apodreceria, "manifestação apenas da noite".

A fala mítica se reporta, por definição, a um passado anterior ao passado, a uma temporalidade que precede e, por isso mesmo, excede à temporalidade; reporta-se assim ao que foi e pode vir a ser, afirmando que o que pôde ter sido para outrem pode vir a ser para ti ou para mim (Lima, 1999: 4). No começo para os ameríndios, "enfim, tudo era humano, ou melhor dizendo, nada era humano" (Danowski \& Viveiros de Castro, 2015: $87)^{14}$. Após uma série de peripécias, parcelas da humanidade originária vão se transformando, de modo espontâneo ou, mais uma vez, em resultado da ação de um demiurgo, nas espécies biológicas, acidentes geográficos, fenômenos meteorológicos e

${ }^{14}$ Déborah Danowski e Eduardo Viveiros de Castro (2015) chama essa era de pré-cosmológica. 
corpos celestes que compõem o cosmos atual. A parcela que não se transformou, permanecendo essencialmente igual a si mesma, é a humanidade histórica, ou contemporânea.

Aqui, coloco em relevo mais algumas versões do mito sobre a origem do fogo, coletadas entre os índios falantes da língua Tupi: os Xetá, os Mbyá-guarani, Xipaia e os Tembé. Nessas versões do mito, os feixes de relações que dizem do fogo de cozinha, proveniente dos urubus ou do gavião, salientam as relações de afinidade potencial ou virtual dos protagonistas com as aves, dos terranos (Danowski e Viveiros de Castro, 2015, p. 123) com um povo celeste, donos do fogo. Esta grande unidade constitutiva diz também do fundamento da cultura humana ou da condição humana. O mito de origem do fogo entre os índios Xetá coletado pela antropóloga C. Silva (2003):

Depois da grande chuva o céu estava ainda muito baixo, e o sol esquentava tanto, que a gente podia assar a caça no calor dele. O calor queimava a pele da gente. Mas, quando o céu se separou da terra, aquele casal de irmão não pôde mais assar a carne, porque não tinha mais o calor do sol que assava tudo e também não tinha fogo. Naquele tempo, quem tinha o fogo era o urubu-de-cabeça vermelha.

O homem então resolveu roubar o fogo do urubu. Porque era ele que tinha o pau de fazer o fogo, que o urubu guardava dentro de um estojo assim. 'Nossa gente também usava'.

Para roubar o fogo do urubu o homem decidiu fazer-se de morto, para atrair o urubu. Deixou o arco e flecha em casa e foi para o mato com a mulher que era irmã dele. Lá construiu um abrigo de folhas para abrigar a irmã, para que ela não fosse percebida pelos animais. Ele fez um apoio de madeira para a cabeça [espécie de travesseiro de madeira] e deitou-se, ficando imóvel, de olhos fechados, fingindo-se de morto. Ele vira carniça, aí vieram às moscas e puseram ovos nele, no couro cabeludo, nos olhos, em todo o corpo, ele virou uma carniça. Dos ovos saíram às varejeiras, que ficaram mexendo nele, mas o homem não se movia, estava morto.

Então, veio o urubu, sobrevoou o lugar, foi baixando aos poucos, pousou numa árvore próxima. Vendo que o homem não se mexia, desceu para o chão e foi espiar ele de perto. Certo de que estava morto mesmo, voou então para ir chamar os outros. Pouco a pouco foi chegando uma porção de corvos e urubus, todas as espécies de urubu. A urubuzada toda veio, até o urubu de cabeça vermelha. Este queria assar o homem. Para isto trouxe o estojo em que guardava o pau de fazer fogo. Ele fez o fogo e passou a arrumar a fogueira. Nisto, o homem abriu um olho para poder ver como o urubu-de-cabeça-vermelha fazia fogo. $\mathrm{O}$ urubu-de-cabeça-vermelha aproximou-se então do homem para vê-lo bem de pertinho. Pegou no seu olho, mas viu que este estava cheio de bichos. Então ele disse:

Está morto mesmo!

Áí todos os outros urubus foram aproximando-se e já estavam erguendo o homem para levá-lo ao fogo, quando este pegou o seu travesseiro-de-pau e com pauladas espalhou os urubus, que voaram assustados. $\mathrm{O}$ homem gritou para a mulher sair do esconderijo e pegar um tição que ele conseguiu pegar. Ela veio rápido, pegou o tição e correu com ele para dentro de casa. Como o urubu de cabeça vermelha voltou para pegar o estojo, ele não queria ir embora, ficou lá no alto da árvore, o homem deitou de novo e continuou lá se fingindo de morto, até que o homem joga o pau no urubu que foge deixando o fogo com o ancestral dos Xetá. O urubu deixa o estojo com o pau de fazer fogo. O homem pegou o estojo com o pau de fazer fogo e esconde no mato. Ele fedia tanto que a irmã pensou que ele estava morto mesmo. Aí eles foram 
para um rio, para o homem se lavar e tirar os bichos de seu corpo. Aí é que a mulher viu como ele estava cheio de varejeiras e pensou que já estivesse morto. Mas ele disse:

_ Ainda sou eu! E começou a tirar os bichinhos e a jogá-los no chão, na margem do rio. (Silva, 2003 apud Viana dos Reis, 2014).

Eis uma versão do mito de origem do fogo entre os índios Guarani-Mbyá ouvida pelo antropólogo Leon Cadogan (1959):

\begin{abstract}
Depois de a primeira terra ter sido destruída por um dilúvio, enviado para castigar uma união incestuosa, os deuses criaram uma segunda terra e para ela enviaram seu filho Ñanderu Papa Miri. Este fez surgirem novos homens, e tratou de lhes dar o fogo, que apenas os feiticeiros-urubus possuíam.

Ñanderu explicou ao filho, o sapo, que se fingira de morto, e que este deveria pegar as brasas assim que ele, retomando os sentidos, as tivesse espalhado.

Os feiticeiros se aproximam do cadáver e consideram-no apropriado para comer. Com o pretexto de ressuscitá-lo, acendem uma fogueira. O herói se mexe e se finge de morto, alternadamente, até que os feiticeiros tenham acumulado uma boa quantidade de brasa. O herói e o filho pegam as brasas e depositam-nas em dois pedaços de madeira que servirão, a partir de então, para produzir fogo por giração. Como punição por seu comportamento antropófago, os feiticeiros serão urubus comedores de carniça, "que não respeitarão a coisa grande" (o cadáver) e que nunca alcançarão a vida perfeita (Cadogan, 1959 apud Lévi-Strauss, 2004: 169-170).
\end{abstract}

Considerando mais de perto este mito de obtenção do fogo pelos Mbyá-Guarani, num estado xamã, Ñanderu acende a posição urubu-feiticeiro - a perspectiva dos urubus-feiticeiros - e, numa economia simbólica da predação (Viveiros de Castro, 2011), o Ñanderu-morto engana os urubus e logra-lhes o fogo. Esse mito não diz da invenção do fogo de cozinha, mas da predação do fogo feita por Nanderu e seu filhosapo, no caso, do domínio do fogo de cozinha realizado pelos urubus-feiticeiros. Outra versão do mito de origem do fogo, agora, colhida entre os índios Xipaia por Curt Nimuendaju (1919):

Para tirar o fogo de uma ave de rapina que o possuía, o demiurgo Kumaphari fingiu morrer e apodrecer. Os urubus devoraram seu cadáver, mas a águia havia colocado o fogo num local seguro. Então o demiurgo finge morrer sob a forma de um cabrito; o pássaro não se deixa enganar. Kumaphari finalmente se transforma em dois arbustos, onde a águia resolve depositar o fogo. O demiurgo pega o fogo, e a águia consente em lhe ensinar a arte de produzir o fogo por friç̧ão (Nimuendaju, 1919 apud Lévi-Strauss, 2004: 170-171).

Entre os índios Tembé, que vivem próximo à foz do rio Tocantins, que desagua no rio Amazonas, Curt Nimuendaju (1915) coletou mais uma versão sobre a origem do fogo: 
Antigamente, o urubu-rei era dono do fogo e os homens tinham de secar sua carne ao sol. Um dia, eles decidiram tomar o fogo e mataram um tapir. Quando seus restos ficaram cheios de vermes, o urubu-rei desceu do céu com os seus. Tiraram as capas de penas e apareceram sob forma humana. Acenderam um grande fogo, envolveram os vermes em folhas e os puseram para assar [cf.Mbaf]. Os homens estavam escondidos perto da carniça e, após uma tentativa fracassada, conseguiram roubar o fogo (Nimuendaju, 1915 apud Lévi-Strauss, 2004, p. 170).

Essas versões do mito de origem do fogo proveniente dos índios falantes da língua Tupi-guarani revelam relações entre afins potenciais elou virtuais, dizem de relações de grande perigo que beira à indiferenciação entre humanos e não-humanos. Os sujeitos, urubu-xamã e petura-xamã se relacionam e consequentemente, ocorre a apreensão da técnica, e consequentemente, do conhecimento tradicional de produção do fogo. O xamanismo, no caso dos mitos, pode ser definido, então, como um modo de obter conhecimento e agência a partir da troca de perspectiva com o mundo de outrem (Kelly, 2001). O mito narra o narrado, falando "pela fala" de um outro (Viveiros de Castro, 2000: 52), como diz Jurusi uhu, índio Zo’é para Dominique Gallois (2000: 37).

Entre imagens fixas e em movimento (vice-versa) (Caixeta de Queiroz, 2008), no caso, dessas versões do mito, os sujeitos, Petura-xamã e urubu-xamã manifestaram a capacidade de cruzar barreiras corporais e adotar a(s) perspectiva(s) de subjetividades não-humanas. Pontos de paragens são também perspectivas.

\begin{abstract}
...discurso "só sujeito", poderíamos igualmente dizer, desta vez falando não da enunciação do discurso, mas de seu enunciado. Ponto de fuga universal do perspectivismo, o mito fala de um estado do ser onde os corpos e nomes, as almas e as ações, o eu e o outro se interpenetram, mergulhados em um mesmo meio présubjetivo e pré-objetivo. Meio cujo o fim, justamente, a mitologia se propõe a contar (Viveiros de Castro, 2011: 355).
\end{abstract}

De certa forma, todos os personagens que povoam os mitos são xamãs. Para conhecê-los instaura-se uma ambiguidade, fabricam-se/enfeitam-se as pessoas, os corpos e artefatos. Há, portanto, algumas passagens, como através dos sonhos, das festas-ritos-sazonais, dos cantos, das danças e da feitura das pinturas corporais e artefatos, para acessar a cosmologia, para tanto, feita, por exemplo, a partir de uma cosmopolítica amazônica.

Com essas versões de mitos apenas quero demonstrar como imagino e consequentemente como consigo traduzir algo que é mais amplo por referir a cosmologia e as histórias dos índios Tapirapé. Neste sentido, no filme Traços Tapirapé 
(Damas, 2016b) é possível verificar mais uma história dita na língua Tapirapé (Tupiguarani) pelo ancião Korako. Este, nos narra o mito Tapirapé, Parageta. Também neste filme, o chefe indígena, o cacique, Kamairao Carlos Xario correlaciona as pinturas corporais (xemoonãwa) com os mitos e a cosmologia quando diz "tem a pintura dos rapazes, das crianças, das moças. São vários tipos e para vários espíritos" (Damas, 2016b). Tudo isto de alguma maneira amplia a nossa imaginação sobre a cosmopolítica amazônica acionada tanto pelo chefe indígena quando juntamente com sua esposa chama as pessoas para começarem a pintar seus corpos para festejar junto com Iraxao como pelos pajés que potencializam suas relações com a floresta, com os axigas, com os espíritos dos índios Iny, com os animais que a habitam, em suma, com os afins virtuais elou potenciais, nos termos de Eduardo Viveiros de Castro (2011).

Pode parecer rápido correlacionar essas imagens fixas e em movimento (viceversa) com o Antropoceno. Mas parece que não é. Uma vez que, os mitos ditos pelos ameríndios que mencionam a destruição do mundo foram recentemente traduzidos como o Primeiro Antropoceno (Danowski e Viveiros de Castro, 2015).

Evidente que dizer isso demonstra como imagino e, consequentemente, como consigo traduzir algo que é mais amplo, por referir não apenas a mitos veiculados pelos índios com uma temática, denominada por Débora Danowski e Eduardo Viveiro de Castro (2015) como Primeiro Antropoceno. Mas também, como os índios Apyãwa (Tapirapé) se posicionam diante do atual Antropoceno. Se algo da cosmopolítica amazônica perpassa o mito sobre a origem do fogo de cozinha contado pelos índios Apyãwa para o antropólogo Charles Wagley (1988: 174). O filme documentário Traços Tapirapé (Damas, 2016b) demonstra tanto o ancião Korako, que nos diz na língua Tapirapé (Tupi-guarani), o mito Tapirapé Parageta, como as legendas em língua portuguesa, uma possível tradução desse mito feita por professores indígenas Apyãwa. Sendo que outra versão desse mito Parageta foi elaborada pelos índios Apyãwa e publicada em um livro denominado Xanetawa Parageta: histórias das nossas aldeias (Tapirapé, 1998).

O povo Tapirapé veio de outro continente. Eles atravessaram o oceano no braço do Camarão. Durante a travessia tinha uma regra que dizia: ninguém pode olhar para trás. Os namorados não podiam olhar para os lados nem para trás. Não podia olhar para ver se outro estava vindo. Foi seguindo essa regra que o povo Tapirapé sobreviveu e conseguiu atravessar o oceano com o braço do Camarão. Mas muitos desobedeceram essa regra e olharam para ver se a namorada ou o namorado estava 
vindo. E então o braço do Camarão se rompeu, muitos ficaram para trás e não conseguiram atravessar o oceano. Os que caíram dentro do mar não conseguiram escapar, pois os jacarés e outros bichos comeram eles. A maioria do povo conseguiu sobreviver e atravessou o mar. Por isso que o povo Tapirapé viveu por muito tempo à beira do mar. Depois de muitos anos morando à beira do mar, o povo Tapirapé resolveu mudar de lá e andaram, andaram até chegarem junto ao povo Javaé. Nessa época nós tivemos muitas guerras. De tanto guerrear o povo Tapirapé foi extinto. Mas ressurgiu através do periquito e do mutum. Graças a eles é que nós crescemos novamente e conseguimos construir uma nova aldeia. De lá para cá o povo Tapirapé passou por muitos lugares e só depois chegou aqui nessa aldeia. E para chegar aqui, eles vieram de canoa até um lugar chamado de Tyha.

De lá o nosso povo veio acompanhando o curso do rio. Quando o povo Tapirapé chegou no varjão, eles se deparam com uma serra. Era a Serra do Urubu Branco. Outros grupos Tapirapé vieram por outros caminhos. Alguns vieram pela divisa do Pará, pelo município de Santana.

Esse povo criou uma aldeia xexetawa. Outro povo criou a aldeia Makotawa, e outro grupo a aldeia Mo'ytawa. Aqueles que vieram pelo rio criaram essa aldeia, Tapi'itãwa. E assim foi criada nossa aldeia Tapi'itãwa (Korako apud Damas, 2016b).

Se o foco é a história (Lévi-Strauss, 2017) em torno da origem da humanidade, é interessante pensar também com as versões dos mitos sobre a origem do povo indígena Iny (Javaé, Ixybiòwa e Karajá). Entre os índios Karajá, o antropólogo Eduardo Nunes (2018) nos diz que dependendo com quem se conversa durante a etnografia as versões se multiplicam. Nunes (2018) encontrou pessoas com as quais estabeleceu uma interlocução para a etnografia e lhe contaram mitos que as levaram a refletir também de forma ampla sobre o território Iny (Karajá, Ixybiòwa e Javaé) e Apyãwa (Tapirapé). Mas também, sobre o surgimento das diversas aldeias e cidades situadas às margens do rio Araguaia. O rio é o marco na vida desses índios e é algo narrado pelas suas histórias.

Para o povo Iny, os primeiros humanos são os "habitantes do fundo do rio" e sofreram um episódio trágico. Essa humanidade primeva foi extinta. Sobreviveram apenas dois irmãos, que irão passar por várias peripécias. O mito traz em seus enunciados a ambivalência e a permeabilidade e numa mesma história percebemos que já havia Iny do lado de fora do rio, pois Karajá, Javaé e Ixybiòwa são os nomes que ficaram historicamente conhecidos. Iny é o termo que os três grupos usam para se autodenominarem. O povo Karajá, e esse é o ponto que Eduardo Nunes (2018) quer acrescentar com sua etnografia, pode funcionar como um modelo para pensar os povos que vivem na calha, próximos ao Araguaia ou em um rio afluente, como o rio Tapirapé. 
Porém, Nunes (2018) buscou também contrastar com sua etnografia algumas outras versões do mito sobre a origem da humanidade coletadas por outros antropólogos e/ou estudiosos sobre os índios Iny. Tal dimensionamento nos é apresentado pelos mitos, que dizem como os grupos se diferenciaram. Tais histórias demonstram que não foi apenas a guerra, como uma troca mal-sucedida, nos termos de Claude Lévi-Strauss (1982), que pode ter pautado a origem da diferenciação entre esses grupos, cada qual indo migrar para outro ponto do território: os índios Javaé, por exemplo, para o interior da Ilha do Bananal. Tais histórias demonstram também que a festa pode ter pautado a origem da diferenciação entre os grupos, sendo que em uma das versões do mito, correspondente a um tempo antigo, entre a primeira humanidade os índios Javaé viviam com os índios Tapirapé. Sobre esta passagem, ver mapa elaborado pela antropóloga Patrícia Rodrigues (2008: 80).

É preciso dizer que Tapirapé é um nome que denomina tanto o rio afluente ao rio Araguaia como os índios que estão historicamente conhecidos por esse etnônimo, pois os índios Tapirapé se autodenominam Apyãwa (Paula, 2012). Esse povo indígena, que vive tanto próximo da foz do rio Tapirapé - numa região de transição do bioma amazônico para o cerrado -, como em outras aldeias situadas mais distantes desse rio, em uma região de floresta tropical próximo à Serra do Urubu Branco, já estiveram relacionados com os índios Iny conforme essas versões dos mitos citados por Eduardo Nuns (2018). Como disse Korako (Damas, 2016b), teve um povo que veio pelo rio e criou Tapi'itãwa, situada próxima à Serra Urubu Branco. 


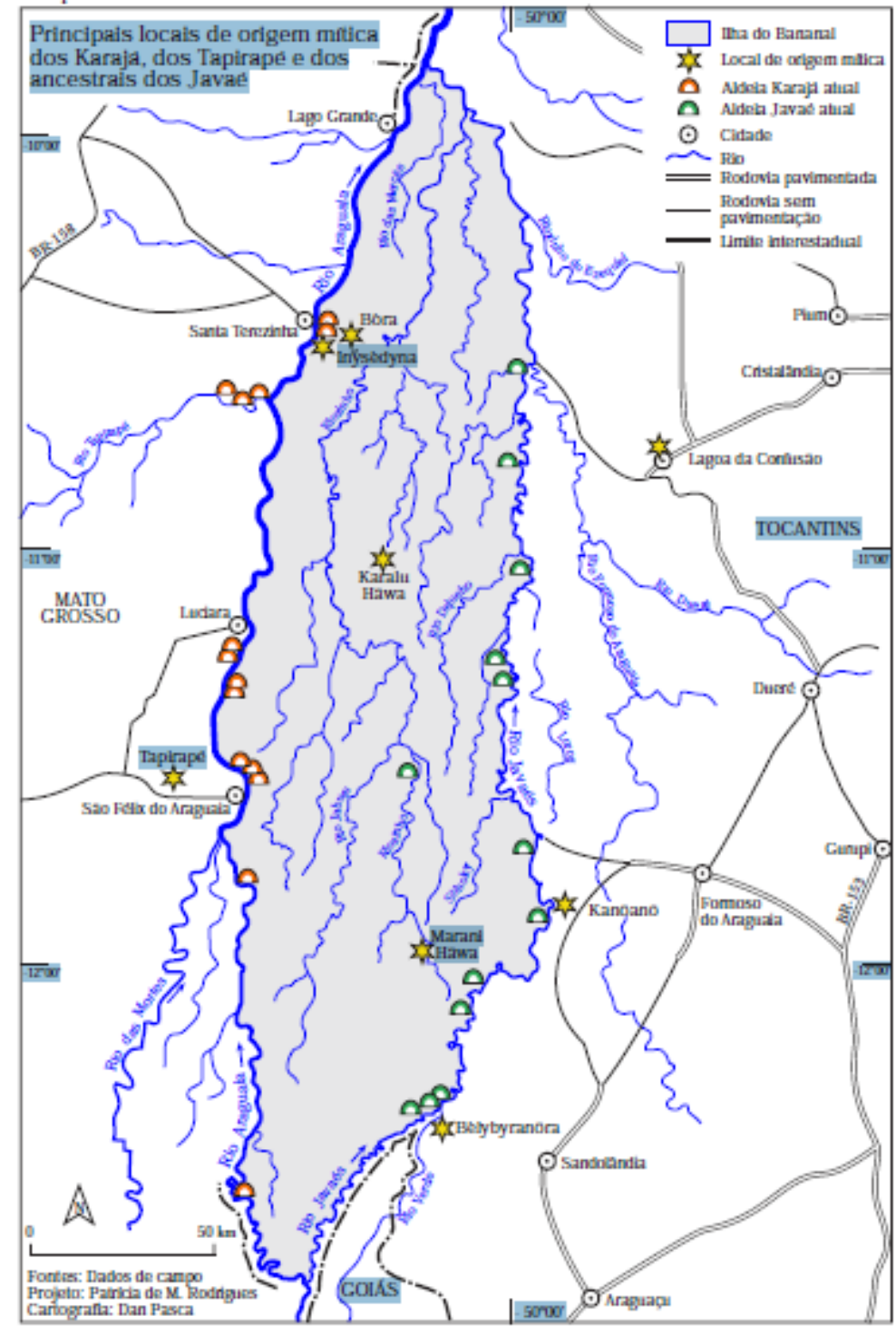

MAPA: principais locais de origem mítica Iny e Apyãwa (Rodrigues, 2008: 80). Acesso de 10 março de 2019.

\section{3 de janeiro de 2019: a festa Iraxao}

No dia 14 de janeiro de 2019, Koria Yrywaxa Tapirapé, professor indígena e mestrando no curso de Antropologia Social do Programa de Pós-Graduação em Antropologia da Universidade Federal de Goiás, me enviou, via WhatsApp, para meu celular Microsoft, 19 fotos feitas durante a festa-rito-sazonal Iraxao, que ocorreu no dia 13 de janeiro de 2019, em Tap'itãwa, situada na Terra Indígena Urubu Branco, Amazônia brasileira. Bem como, as fotos produzidas dentro da Takãra, relacionadas ao 
feitio das máscaras-xamãs, dia(s) antes da festa-rito-sazonal Iraxao acontecer conforme o calendário do tempo (Tapirapé 2007, 2009a) dos Apyãwa.

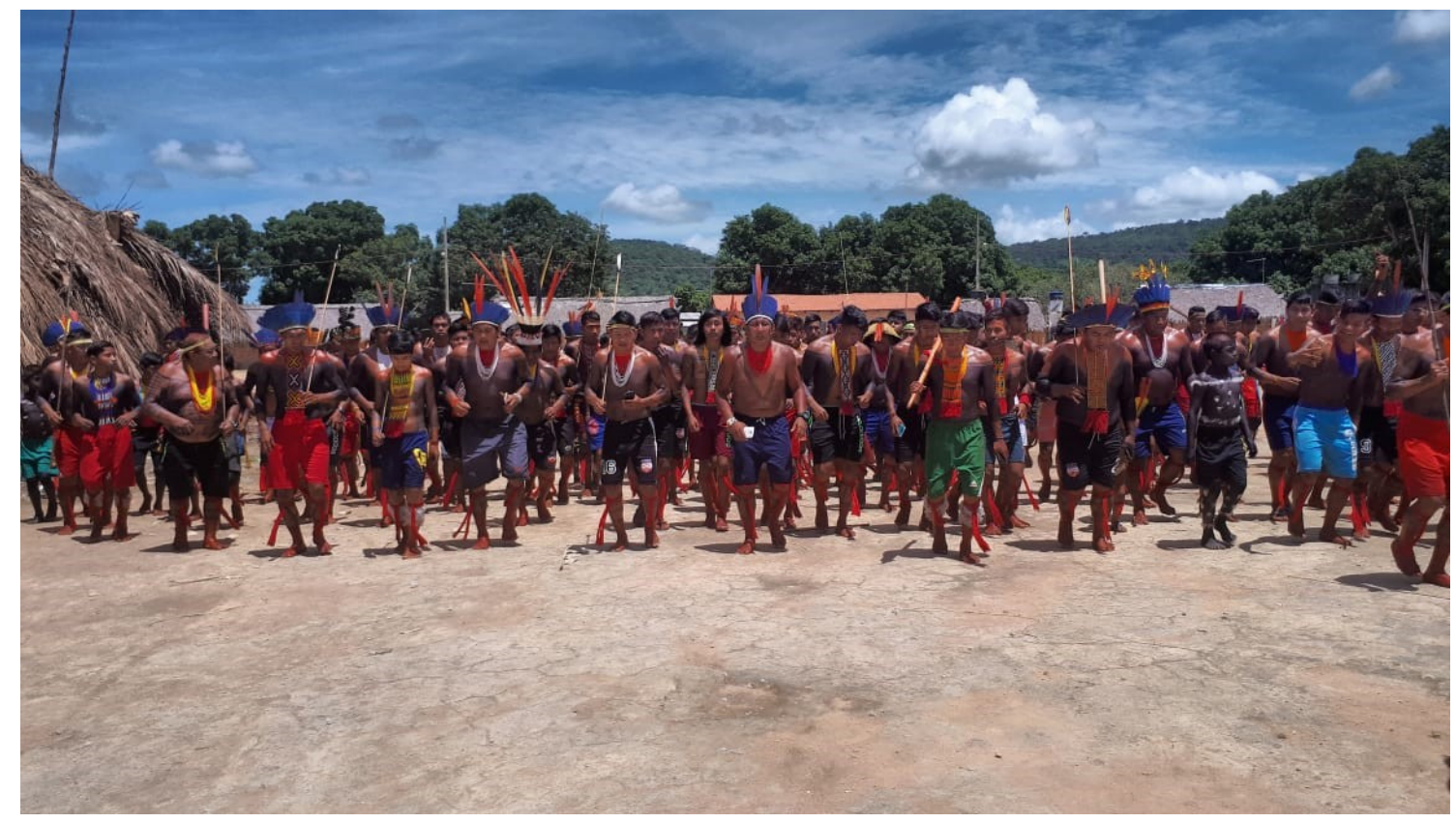

Fotógrafo: Koria Yrywaxa Tapirapé. Festa-rito-sazonal Iraxao. 13 de janeiro de 2019.

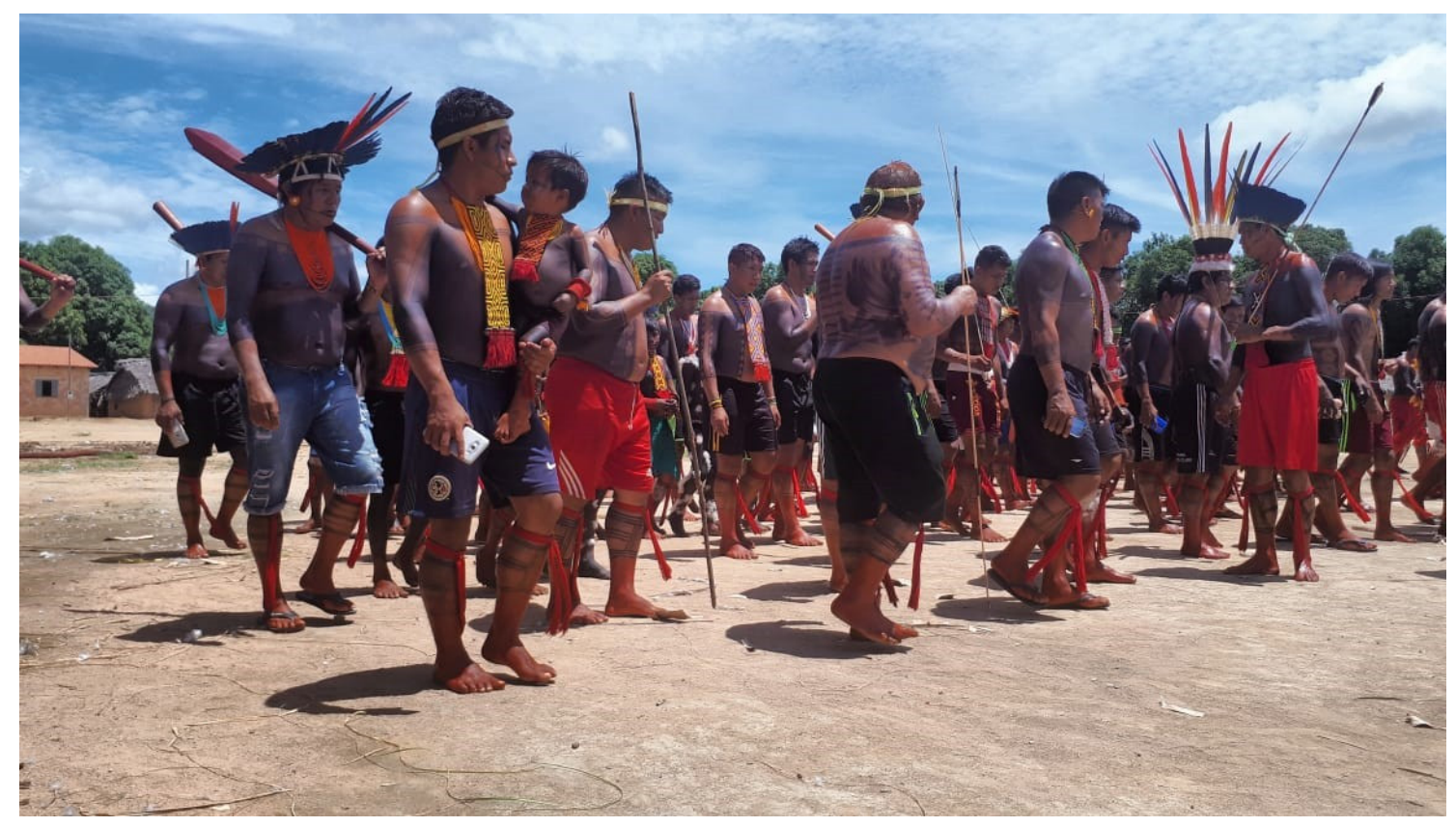

Fotógrafo: Koria Yrywaxa Tapirapé. Festa-rito-sazonal Iraxao. 13 de janeiro de 2019. 


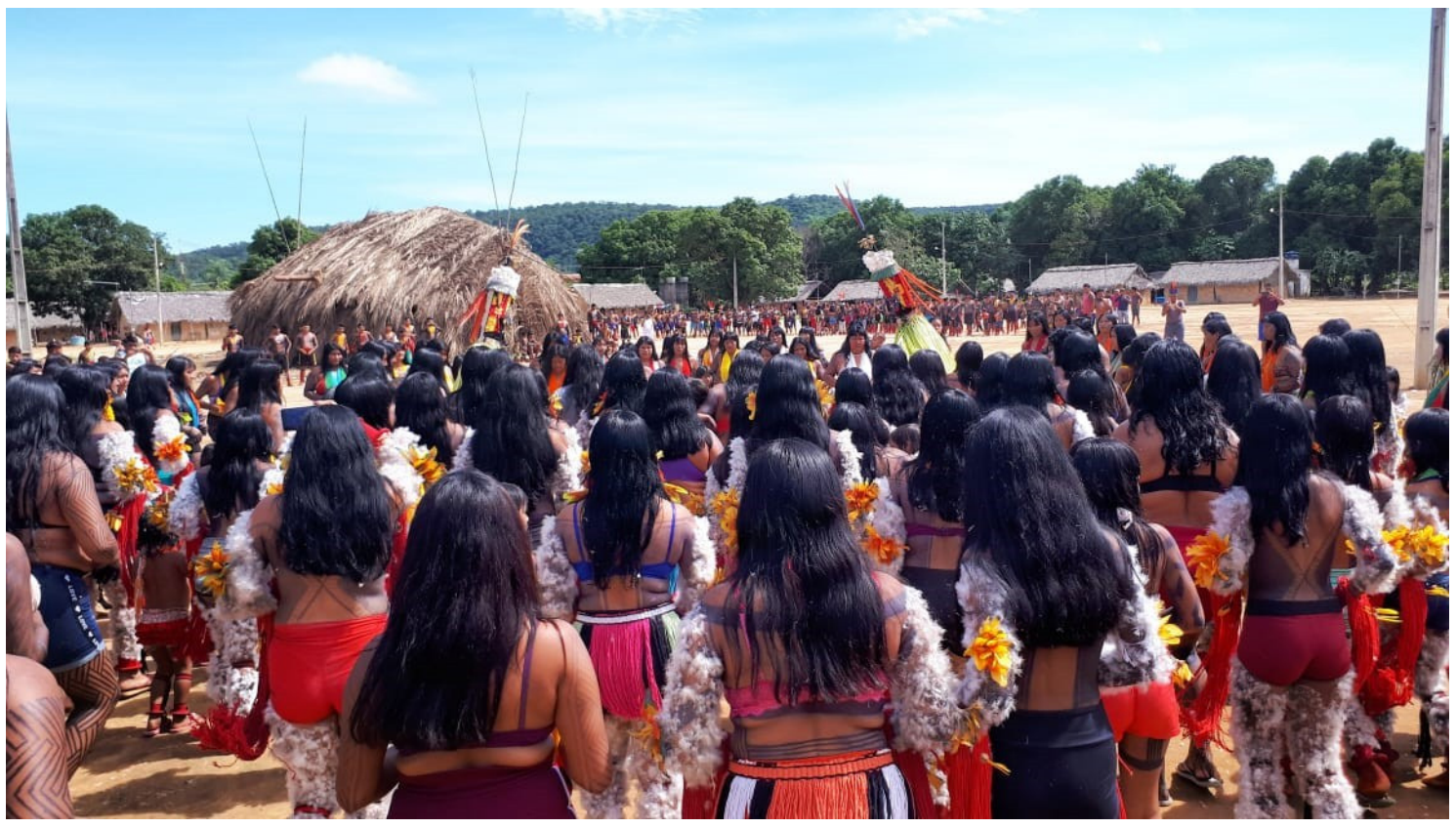

Fotógrafo: Koria Yrywaxa Tapirapé. Mulheres com pinturas corporais e enfeites para a festa-rito-sazonal Iraxao. 13 de janeiro de 2019.

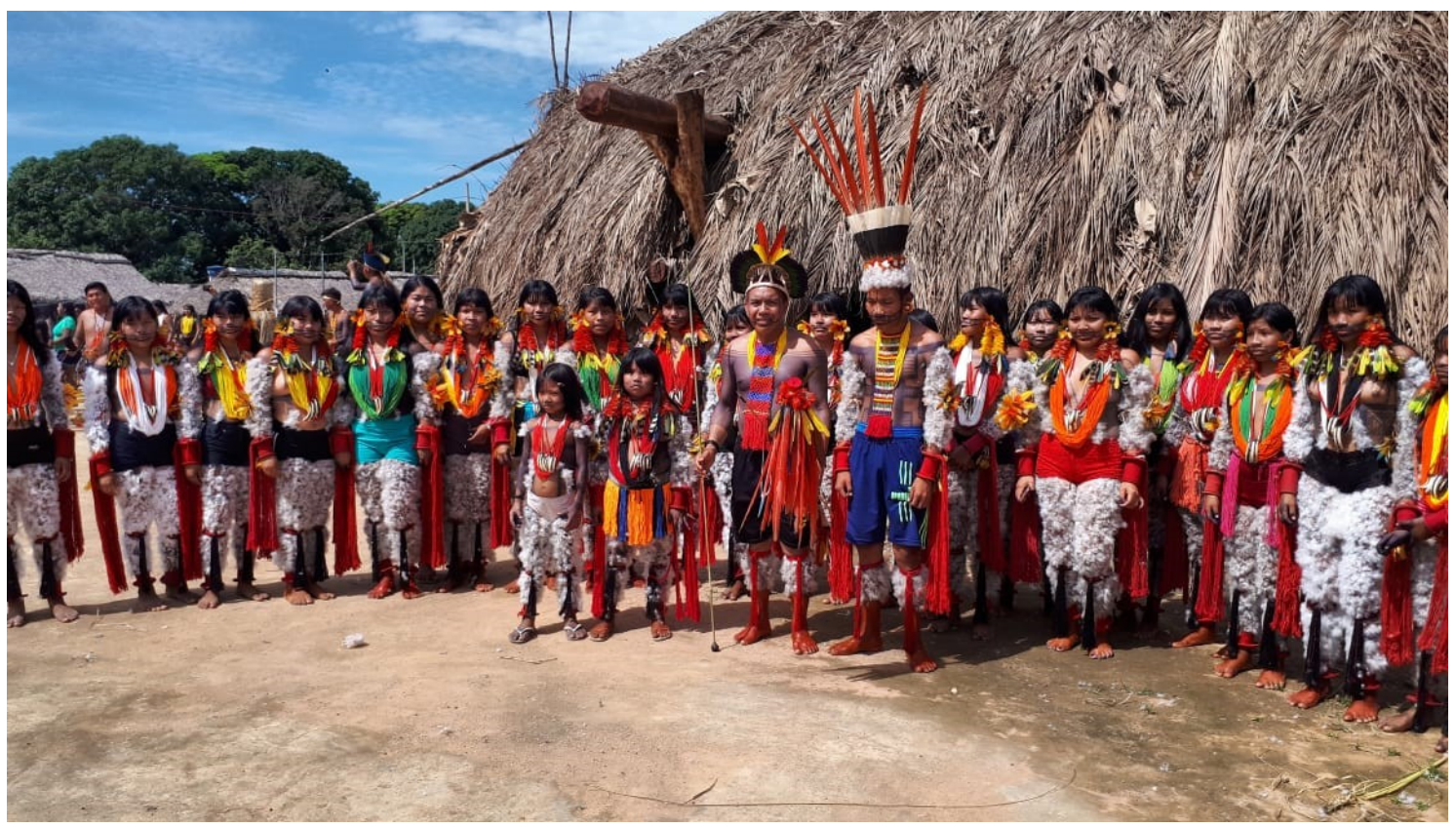

Fotógrafo: Koria Yrywaxa Tapirapé. Festa-rito-sazonal Iraxao. 13 de janeiro de 2019. 


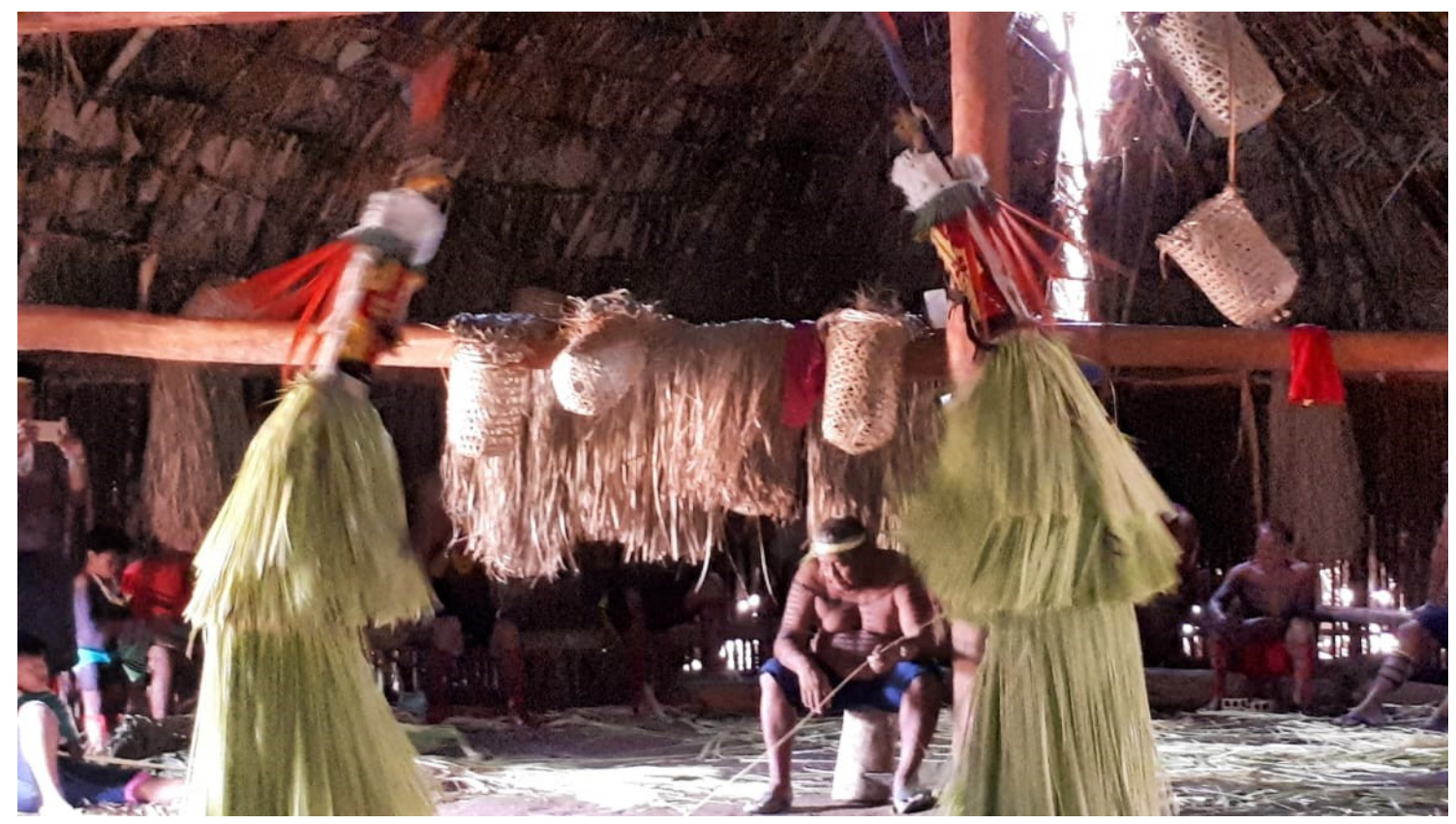

Fotógrafo: Koria Yrywaxa Tapirapé. Associação Pássaro e par de máscaras-xamãs dentro da takãra. Festa-rito-sazonal Iraxao. 13 de janeiro de 2019.

\section{Linhas, pontos e traços Apyãwa: os Grafismos indígenas}

Em algumas imagens fixas e em movimento (vice-versa) (Caixeta de Queiroz, 2008) do filme Traços Tapirapé (Damas, 2016b) são demonstradas uma pintura corporal (xemoonawã) feita com tinta de jenipapo, que indica um grafismo singular feito de linhas, pontos e traços para a festa-rito-sazonal Iraxao. Tal pintura é realizada por uma mulher em um corpo de outra mulher e indica possíveis fractalidades (Kelly, 2001) com as pinturas corporais registradas por mim (Viana dos Reis e Marques Damas, 2018) e Vandimar Marques Damas de dentro da Takãra no dia 12 de janeiro de 2017 (ver fotos acima) e com as pinturas corporais demonstradas nas fotos feitas por Koria Yryrwaxã Tapirapé durante a festa-rito-sazonal Iraxao do dia 13 de janeiro de 2019 (ver fotos acima). Aqui, busco demonstrar que esse ato de fazer corpos e parentesco demonstra simultaneamente às estruturas que estruturam os consanguíneos e os afins (Viveiros de Castro, 2011) e os modos de tradução via pintura corporal que também demonstram algo de uma cosmopolítica amazônica. Pois, neste caso as mulheres Apyãwa também estabelecem relações e vínculos com os afins potenciais e virtuais. Como nos narra a professora indígena Makato Tapirapé no documentário Traços Tapirapé: 
O gavião matou a avó da tartaruga. Aí, quando a tartaruga matou o gavião, aí, o peixe se pintava todinho com o sangue, com gordura. Então, diz que o nosso pajé viu a pintura, viu como os peixes, as aves, os animais se pintavam. Aí, ele trouxe a pintura, foi assim que veio a pintura para o povo Apyãwa (Damas, 2016b).

Neste sentido, posso dizer que essas mulheres estão xamãs ao pintarem os corpos e fabricarem o parentesco? Para tanto, parto de três premissas: (i) N. Troubetzkoy (1933) resume o método fonológico a quatro procedimentos fundamentais: em primeiro lugar, a fonologia passa do estudo dos fenômenos linguísticos conscientes para o de sua infraestrutura inconsciente; recusa-se a tratar os termos como entidades independentes, tomando como base sua análise, ao contrário, as relações entre os termos; introduz a noção de sistema - "A fonologia atual não se limita a declarar que os fonemas são sempre membros de um sistema, ela mostra sistemas fonológicos concretos e evidencia sua estrutura" (Troubetzkoy, 1933 apud Lévi-Strauss, 2012: 60) finalmente, ela visa à descoberta de leis gerais, descobertas ou por indução, "ou deduzidas logicamente, o que lhes dá um caráter absoluto" (Lévi-Strauss, 2012: 60). (ii) Toda cultura estabelece uma antinomia entre o dado e o construído, conforme pontua Roy Wagner (2010), no que tange ao parentesco ameríndio (Viveiros de Castro, 2011), a consanguinidade constitui o âmbito do construído, o que se relaciona com a intenção e a ação humana atualizarem. Quanto à afinidade, tem função de dada na matriz relacional cósmica. (iii) "As pessoas são integralmente constituídas por relações” (Viveiros de Castro, 2015). E essas relações não se restringem aos consanguíneos e afins de um dado grupo local, elas se estendem para os afins virtuais ou potenciais, nomeados como rios, animais, espíritos, vegetais, imagens, por exemplo. A perspectiva sugerida por Eduardo Viveiros de Castro (2015) para uma teoria do parentesco enquanto diferença e multiplicidade trata-se de não negligenciar os mitos. Por que retornar ao mito?

O recurso ao mito é indispensável, não porque ele seja uma representação transposta ou mesmo invertida das relações reais em extensão, mas porque é só ele que determina, conforme o pensamento e a prática indígenas, as condições intensivas do sistema (inclusive do sistema de produção) responde Deleuze e Guattari (apud Viveiros de Castro, 2015: 141).

Assim, o grafismo indígena expresso a partir das linhas, pontos e traços está sendo visto e pensado não como um padrão cultural, e sim, como mais uma maneira de 
compor diferentes corpos e fazer parentesco à medida que a pintura corporal está conectada com os mitos. Há variados grafismos, sendo que a pintura corporal sobre a pele de cada pessoa entrelaça-se com o gênero e a idade e cada qual revela tanto uma variação na composição dos corpos e na feitura do parentesco como demonstram algo da cosmopolítica amazônica.

\section{A festa Iraxao e a cosmopolítica amazônica}

Durante os momentos de preparação da festa Iraxao em janeiro de 2017, Karaxipa, professor indígena e anfitrião dessa festa, também veio falar conosco com o uso da língua portuguesa sobre o tempo da seca muito prolongado. Isto ocasionou no início do tempo das chuvas uma escassez dos alimentos fundamentais para as comidas para todos festejarem durante essa festa Iraxao. Odila ${ }^{15}$, Irmãzinha de Jesus, também compartilhou essa preocupação conosco, quando nos recebeu em sua casa e conversou conosco sobre tal situação.

Para chegar à Terra Indígena Urubu Branco, viajei à Terra Indígena de ônibus durante dois dias pelas rodovias brasileiras que cortam os estados de Minas Gerais, Goiás e Mato Grosso e pela janela vislumbrei as transformações nas paisagens. Sobremaneira, as realizadas pela ação humana e sem desconsiderar a agência dos não humanos, seja com a expansão da urbanização seja com a instauração e expansão do agronegócio seja com a presença de indústrias. Quando Karaxipa nos contou e compartilhou conosco sua preocupação pela falta desses alimentos, logo conectei com o dito Antropoceno ou com o dito Capitaloceno (Haraway, 2017) ou com a expressão mais difundida pelas razões dessa nova era, a saber, o aquecimento global, as mudanças climáticas e o desmatamento da Amazônia (cerrado e floresta tropical e equatorial). Tudo isto pode contribuir para uma melhor tradução da falta de alimentos em abundância durante a festa Iraxao.

Neste sentido, a escassez de alimentos no tempo das chuvas para preparação das principais comidas e bebida para a festa Iraxao nos pareceu que foi uma sinalização forte das transformações que todos estamos vivendo com o Antropoceno. É importante

15 O documentário Veva Tapirapé https://www.youtube.com/watch?v=M2mWTgDVphQ demonstra algo da historia das Irmãzinhas de Jesus entre os índios Tapirapé. 
mencionar que os índios Apyãwa chegaram a conceder duas entrevistas, uma para o periódico Amazônia Real ${ }^{16}$ e a outra para A Pública - Agência de Jornalismo Investigativo $^{17}$ para comunicarem que as águas (córregos) secaram dentro de seu território. Isto quer dizer que o rio Tapirapé, em um dado trecho, foi encontrado seco ou com o nível muito abaixo do recomendado. Isto demonstra que suas histórias foram ampliadas por meio de algumas mídias de comunicação preocupadas também com o Antropoceno, com o Capitaloceno e com a Ecologia. Nestas entrevistas publicadas para esses periódicos é possível notar a percepção dos índios Apyãwa não só sobre o tempo da seca prolongado vivenciado na Terra Indígena Urubu Branco como também sobre o desmatamento, a contaminação do solo e das águas por conta da difusão do agrotóxico e do avanço do agronegócio.

Assim, tal preocupação com o atual Antropoceno tem levado os índios Apyãwa, que já conhecem o Primeiro Antropoceno (Danowski e Viveiros de Castro, 2015), a encontrar e a estabelecerem relações com os brancos e com os não-indígenas para narrar tais transformações que não são apenas históricas, mas também cosmológicas. Portanto, conectadas com a cosmopolítica amazônica que somente funcionam a partir de relações de afinidade potencial e virtual e consaguinidade como verificado na festa Iraxao.

\section{Notas finais}

$\mathrm{O}$ intuito não é somente demonstrar como algumas relações de afinidade potencial e virtual são traduzidas como algo do escopo da cosmopolítica amazônica acionadas pelos índios Apyãwa e podem contribuir para se pensar algo dos contrastes das cosmopolíticas (Stengers, 2014-2015), atualmente vivenciadas entre os índios Apyãwa (Tapirapé) e Iny em seus territórios tradicionais. O presente artigo buscou sugerir que é possível conhecer ${ }^{18}$, especificamente, algo dessa cosmopolítica amazônica

\footnotetext{
${ }^{16}$ Ver a reportagem $A$ cada dia que passa temos menos água na Terra Indígena Urubu Branco dos Apyãwa do jornalista Fabio Zuker publicada no dia 25 de maio de 2018: http://amazoniareal.com.br/acada-dia-que-passa-tem-menos-agua-na-terra-urubu-branco-dos-apyawa/

${ }^{17}$ No dia 19 de agosto de 2019, publicou algumas reportagens que abordam os conflitos socioambientais enfrentados cotidianamente pelos índios Apyãwa e Iny, ver Tem veneno no conflito escrito pelos jornalistas Julia Dolce e José Cícero Silva, ver: https://apublica.org/2019/08/tem-veneno-no-conflito/

${ }^{18}$ Este artigo ancora-se em algumas comunicações referentes a alguns momentos de imersão realizados ao longo do doutoramento em antropologia social. Tais comunicações foram feitas em diferentes eventos 
(Viveiros de Castro, 2008) quando se realiza o contraste entre as imagens técnicas e conceituais a ponto de dizer algo para além das visualidades em si tomando como partido uma concepção mais ampla, posta na definição do que são as imagens fixas e em movimento (vice-versa) (Caixeta de Queiroz, 2008). Tanto os vídeos digitais que narram os momentos vividos pelos índios Apyãwa e Iny durante a festa Iraxao realizada, conforme calendário do tempo (Tapirapé, 2007; Tapirapé, 2009a) como o uso das fotos antigas e atuais no âmbito deste momento etnográfico que reportam as variadas redes de relações empreendidas pelos índios Tapirapé (Apyãwa), entre si e entre outrem, especialmente, entre os brancos e os índios Iny (Karajá, Javaé e Ixybiòwa).

Embora conhecer por imagens seja estar situado mais entre o sensivel $e o$ inteligível (Caixeta de Queiroz, 2012) busquei acionar com este momento de escrita algo proveniente dos momentos de imersão entre os índios Apyãwa (Tapirapé) e Iny. Mas também, nas diversas instituições que guardam documentos audiovisuais e objetos etnográficos, sem desconsiderar os momentos de leituras e escutas correlacionadas com os índios Apyãwa e Iny. Ou seja, este momento etnográfico ao vislumbrar no horizonte algumas versões dos mitos, ouvidas e registradas por outrem, fotos, filmes e documentos registrados por outrem e ao conectar-me com esse emaranhado de dados e entrelaçá-los neste momento de escrita, procurei também demonstrar como este momento etnográfico foi multissituado. Isto se torna ainda mais intenso, quando aciono também os compartilhamentos feitos com os índios, que atualmente, e cada vez mais, compõem a comunidade universitária, como com o professor e antropólogo Yrywaxa ${ }^{19}$, que fez filmes e fotografias das festas-ritos-sazonais, compartilhou comigo algumas dessas fotos e filmes, no âmbito do plano de trabalho Antropologia compartilhada entre os índios Apyãwa (Tapirapé): cinema e etnografia (Viana dos Reis e Caixeta de Queiroz, 2018; Viana dos Reis, 2019).

Nota-se que os índios Apyãwa (Tapirapé) buscam compartilhar e multiplicar as histórias correlacionadas não só com o Primeiro Antropoceno, mas também as narrativas imbricadas com o Antropoceno (conflitos socioambientais e aquecimento global), na medida em que as relações com as quais se envolvem estão marcadas por um

científicos que ocorreram em 2015, 2016 e 2018 e estão publicadas no artigo O filme Traços Tapirapé: Iraxao e o antropoceno (Viana dos Reis, 2018).

19 Tais compartilhamentos ocorreram tanto no âmbito do Núcleo Takinahaky de Formação Superior Indigena - UFG como pelas redes sociais digitais Facebook e Whatsapp. 
posicionamento de fabricação de parentesco, entre corpos e pessoas, logo de posicionamentos que demonstram uma cosmopolítica amazônica como os vínculos estabelecidos durante a festa-rito-sazonal Iraxao, que ocorre no tempo das chuvas, também demonstram algo dessa cosmopolítica singular. Nesta direção, vínculos com os afins potenciais e virtuais: espíritos, vegetais, animais, artefatos... Como disse Herbert Baldus (1970), as festas para os índios Tapirapé garantem a manutenção de um bom estado de saúde. O que faz dos territórios indígenas - as casas, a Takãra, os terreiros, as roças e a floresta - lugares detentores das forças vitais fabricadas cotidianamente por meio dos conhecimentos tradicionais e tudo isto garante a perpetuação do modo de vida dos índios Apyãwa e Iny.

Ao final é possível, então, concluir que este artigo não teve como foco principal, apenas, demonstrar a localização de algumas das ações políticas e dinâmicas acionadas pelos índios Apyãwa e Iny. E sim, eleger as imagens fixas e em movimento (vice-versa) como: a) possíveis passagens para ontologias relacionais; b) um exercício de pensamento, que articula tanto a invenção como a convenção; c) histórias e d) traduções de algo da cosmopolítica amazônica.

\section{REFERÊNCIAS}

BALDUS, Herbert. Aspectos da organização social tapirapé: tripartição, dualidade e graus de idade. Revista do Museu Paulista, São Paulo, vol. XVII. (82), (83). 1967.

BALDUS, Herbert. Tapirapé: Tribo tupí no Brasil Central. Edusp, Companhia Editora Nacional, SP, 513p., 1970.

BAZIN, André. Ontologia da Imagem fotográfica. In: A experiência do cinema antologia, Ismail Xavier (org). Rio de Janeiro: Ed. Graal: Embrafilme. 1983.

CAIXETA DE QUEIROZ, Ruben. Do movimento ao fixo (e vice-versa) em LéviStrauss. In: CAIXETA DE QUEIROZ, R. \& FREIRE NOBRE, R. (Orgs.). LéviStrauss: leituras brasileiras. Belo Horizonte: Editora UFMG, 2008.

CUNHA, Manuela Carneiro da. Cultura com aspas e outros ensaios. São Paulo: Cosac 
Naify, 2009.

CLASTRES, Pierre. Sociedade contra o estado: pesquisas de Antropologia Política. São Paulo: Cosac Naify, 2003.

DANOWSKI, Déborah \& VIVEIROS DE CASTRO, Eduardo. Há mundo por vir? Ensaio sobre os medos e os fins. Desterro [Florianópolis]: Cultura e Barbárie: Instituto Socioambiental, 2015.

EDWARDS, Elizabeth. Rastreando a fotografia. In: BARBOSA, Andrea [et al.] (orgs). A experiência da imagem etnográfica. São Paulo: Terceiro Nome/Fapesp, pp. 153-190. 2016.

FLUSSER, Vilém. Filosofia da Caixa Preta: ensaios para uma futura filosofia da fotografia. São Paulo: Annablume, 2011.

FRANCE, Claudine de. Do filme etnográfico à antropologia fílmica. Tradução Marcius Freire. Campinas: Editora da Universidade Estadual de Campinas-Unicamp, 2000.

GALLOIS, Dominique, JURUSI UHU, PA'I e TATITU. Narrativas Zo'é. Jipohan é gente como você. In: RICARDO, Carlos Alberto (org.). Povos Indígenas no Brasil, 1996-2000. São Paulo: Instituto Socioambiental. p. 36-37. 2000.

KOSSOY, Boris. Fotografia \& História. 2a edição. São Paulo: Ateliê Editorial, 163p., 2001 .

LATOUR, Bruno. A esperança de pandora. Bauru: EDUSC. 2001.

LEROI-GOURHAN, André. Cinema et sciences humaines. Le film ethnologique existet-il? Revue de Géographie Humaine et d'Ethnologie. 3, p. 42-50. 1948.

LÉVI-STRAUSS, Claude. As estruturas elementares do parentesco. Petrópolis: Vozes. [1949] 1982.

LÉVI-STRAUSS, Claude \& ERIBON, Didier. De perto e de longe. Tradução Léa Mello e Julieta Leite. Editora: Nova Fronteira, 235p., 1990. 
LÉVI-STRAUSS, Claude. História de Lince. Tradução Beatriz Perrone-Moisés. São Paulo, Companhia das Letras, 243p.,1993.

LÉVI-STRAUSS. Claude. O cru e o cozido: Mitológicas I. Tradução Beatriz PerroneMoisés. São Paulo: Cosac Naify, 442p., 2004.

LÉVI-TRAUSS, Claude. A origem dos modos à mesa: Mitológicas III. Tradução Beatriz Perrone-Moisés. São Paulo: Cosac Naify, 2006.

LÉVI-STRAUSS, Claude. Antropologia estrutural. Tradução Beatriz Perrone-Moisés. $1^{\mathrm{a}}$ edição. São Paulo: Cosac Naify, 2012. 608p.

LÉVI-STRAUSS, Claude. O pensamento selvagem. Tradução Tânia Pellegrini. $12^{\text {a }}$ edição. $3^{\text {a }}$ reimpressão. Campinas, Papirus. 336p., [1962] 2014.

LÉVI-STRAUSS, Claude. Antropologia estrutural dois. Tradução: Beatriz PerroneMoisés. São Paulo: Ubu, 2017.

LIMA, Tânia Stolze. Um Peixe Olhou Para Mim. O povo Yudjá e a perspectiva. São Paulo: UNESP/ ISA/ NUTI. 2005.

LINDEPERG, Silvie. O destino singular das imagens de arquivo: contribuição para um denate, se necessário, uma "querela". Revista Devires - Cinema e Humanidades. Dossiê Documentário e Cinema de Arquivo, v. 12, n. 1, p. 12-27. 2015.

MALINOWSKI, Bronislaw. Argonautas do Pacifico ocidental: um relato do empreendimento e da aventura dos nativos nos arquipélagos da Nova Guine Melanésia. 2. ed. São Paulo: Abril Cultural, 1978.

MELIÁ, Bartolomeu. Apresentação. In: PISSOLATO, Elizabeth. A duração da pessoa: mobilidade, parentesco e xamanismo mbya (guarani). São Paulo/Rio de Janeiro: Editora da UNESP/Nuti-Pronex. 2007.

RIVIERE, Peter. Indivíduo e sociedade na Guiana. São Paulo: Edusp, 2001.

ROCHA, Margarida Nogueira. Oralidade e escrita: funções sociocomunicativas em uma organização tribal. Tese (Doutorado), Universidade de São Paulo, São Paulo.1997. 
SAMAIN, Etienne. "Ver" e "dizer" na tradição etnográfica: Bronislaw Malinowski e a fotografia. Horizontes Antropológicos. Porto Alegre, ano 1, n. 2, p. 23-60, jul./set. 1995.

STEWARD, Julian H. (org). Handbook of South American Indians. Washington: Smithsonian Institution. Bureau of American Ethnology, v. 1-7, 1946-1959.

STRATHERN, Marilyn. Artefatos da história: os eventos e a interpretação de imagens. Tradução Iracema Dulley. FERRARI, Florencia (org). O efeito etnográfico e outros ensaios. São Paulo: Cosac Naify. 2014.

STRATHERN, Marilyn. O efeito etnográfico. Tradução Iracema Dulley. FERRARI, Florencia (org). O efeito etnográfico e outros ensaios. São Paulo: Cosac Naify. 2014.

TAPIRAPÉ, Comunidade. Xanetawa Parageta: histórias das nossas aldeias. São Paulo/ Brasília: Mec/Sef/Mari, 1998.

TAPIRAPÉ, Arakae... [et al]. Matemática Tapirapé: sistema de contagem, marcadores de tempo e medidas. Tradutores: TAPIRAPÉ, A. Orokomy'i \& TAPIRAPÉ, Carlos Xario'i. SILVA, A. A. da (Org.). Confresa: Projeto de Ensino Médio: Aranowa’yao Novo Pensamento, 2007.

TAPIRAPÉ, Karaxipa. Iraxao. In: TAPIRAPÉ, Nivaldo Korira'i (Org.). Festas e rituais Tapirapé. Faculdade Indígena Intercultural, UNEMAT, Barra do Bugres, MT, 2009b.

TAPIRAPÉ, Carlos Xario'i. Cantos do Xarowi. FRANCHETTO, Bruna. Pesquisas indígenas na Universidade. Série de Textos Indígenas. Rio de Janeiro: Museu do Índio - Funai, 171-210p. 2010.

VIANA DOS REIS, Paula Grazielle. Vladimir Kozák, as câmeras e os Xetá. Dissertação de mestrado em antropologia social. Orientador: Ruben Caixeta de Queiroz. Programa de Pós-graduação em Antropologia (Fafich). Universidade Federal de Minas Gerais. Belo Horizonte. 2014.

VIVEIROS DE CASTRO, Eduardo. Araweté: Os deuses canibais. Rio de Janeiro: Jorge Zahar Editor Ltda, [1984] 1986. 
VIVEIROS DE CASTRO, Eduardo. Xamanismo transversal: Lévi-Strauss e a cosmopolítica amazônica. In: CAIXETA DE QUEIROZ, R. \& FREIRE NOBRE, R. (Orgs.). Lévi-Strauss: leituras brasileiras. Belo Horizonte: Editora UFMG, 2008.

VIVEIROS DE CASTRO, Eduardo. A inconstância da alma selvagem e outros ensaios de antropologia. $2^{\mathrm{a}}$ edição. $1^{\mathrm{a}}$ reimpressão. São Paulo: Cosac \& Naify. [2002] 2011.

VIVEIROS DE CASTRO, Eduardo. Metafisicas canibais: elementos para uma antropologia pós-estrutural. $1^{\text {a }}$ edição. São Paulo: Cosac \& Naify, 288p. 2015.

WAGLEY, Charles e GALVÃO, Eduardo. The Tapirapé. Handbook of South American Indians III. Washington: Smithsonian Institution. Bureau of American Ethnology. Bulletin 143, 1948.

WAGLEY, Charles. Welcome of tears: the Tapirapé Indians of Central Brazil. Nova York, 1977.

WAGLEY, Charles. Lágrimas de boas-vindas: os índios Tapirapé do Brasil Central. Tradução Elisabeth Mafra Cabral Nasser. Belo Horizonte: Editora Itatiaia Limitada.1988.

WAGNER, Roy. A invenção da cultura. Tradução Marcela Coelho de Souza e Alexandre Morales. São Paulo: Cosac \& Naify: 247p., 2010.

\section{Documentos eletrônicos:}

ANDRADE, Maria Júlia Gomes. A construção da Takãra em Majtyri: etnografia de uma aldeia Tapirapé. 2010. Dissertação (Mestrado em Antropologia) - Programa de Pós-graduação em Antropologia, Universidade Federal Fluminense, Rio de Janeiro, 2010.

BALDUS, Herbert. Fotografias: código TA 076 e 077. In: Banco de dados do LISALaboratório de Imagem e Som em Antropologia.1947. 
BALDUS, Herbert. Os grupos de comer e os grupos de trabalhos dos Tapirapé. Ensaios de Etnologia brasileira, p. 86-100. 1937.

BOURDIEU, Pierre e BOURDIEU, Marie-Claire. O camponês e a fotografia. Revista de Sociologia e Política. n26, p. 31-39, 2006.

CAIXETA DE QUEIROZ, Ruben. Between the sensible and the intelligible: Anthropology and the cinema of Marcel Mauss and Jean Rouch. Vibrant - o Virtual Brazilian Anthropology, v.9, n. 2, 2012.

COELHO DE SOUZA, Marcela. Nós os vivos: construção da pessoa e 'construção do parentesco' entre alguns grupos jê. Revista Brasileira de Ciências Sociais, 16(46), p. 69-96. 2001.

COELHO DE SOUZA, Marcela. O traço e o círculo: o conceito de parentesco entre os Jê e seus antropólogos. Tese (Doutorado em Antropologia Social) - Museu Nacional. Rio de Janeiro, Universidade Federal do Rio de Janeiro. 2002.

DAMAS, Vandimar Marques. "Pintura corporal e xamanismo: experiência sobre a produção de um vídeo entre os Tapirapé”. Anais [do] Encontro Internacional de Antropologia Visual, 03 a 08 de novembro de 2014 [recurso eletrônico]/ Sylvia Caiuby Novaes (org.). São Paulo: FFLCH/USP, 2015.

DAMAS, Vandimar Marques. Vermelho e negro: Beleza, sentimentos e proteção entre os Tapirapé. Tese (Doutorado em arte e cultura visual). Faculdade de Artes Visuais, Universidade Faculdade de Goiás, Goiânia, 2016a.

DAMAS, Vandimar Marques. Trabalho de campo através das imagens: reflexões entre o filme “Traços Tapirapé”. Anais do I Encontro de Fotografia, Cinema e Artes digitais. MARTINS, Alice Fátima \& RIBEIRO, José da Silva (orgs.). Dados eletrônicos. Goiânia: Gráfica UEG/UFG, 2017.

GALVÃO, Eduardo \& WAGLEY, Charles. O parentesco Tupi-guarani. Boletim do Museu Nacional: Antropologia, n 6, p. 1-23, 1946. http://www.ppgasmnufrj.com/uploads/2/7/2/8/27281669/boletim_do_museu_nacional_06.pdf 
GOLDMAN, Marcio. Alteridade e experiência: Antropologia e teoria etnográfica. Etnográfica, Lisboa, v. 10, n. 1, maio 2006.

HANNERZ, Ulf. Being there... and there... and there! Reflections on multi-site ethnography. Ethnography. Vol 4 (2), p. 201-216. 2003.

HARAWAY, Donna. Antropoceno, Capitaloceno, Plantationoceno, Chthuluceno: fazendo parentes. In VALE, G.; TORRES, J.; ITALIANO, C. (Org.). $21^{\circ}$ Festival do filme documentário e etnográfico/ Fórum de Antropologia e Cinema- ForumdocBH 2017. Belo Horizonte: Catálogo. Associação Filmes de Quintal/ Imprensa Universitária da UFMG, p.132-139. 2017. Disponível em http://www.forumdoc.org.br/catalogos/catalogo forumdoc 2017.pdf

KELLY, J. Fractalidade e troca de perspectivas. Mana, v. 7, n. 2, p. 95-132, 2001.

LIMA, Tânia Stolze. O pássaro de fogo. Revista de Antropologia, São Paulo, v. 42, n. 12, pp.113-132. 1999.

NUNES, Eduardo. Transformações Karajá. Os "antigos" e o "pessoal de hoje" no mundo dos brancos. Tese (Doutorado em Antropologia social) - Departamento de Antropologia, Universidade de Brasília, 2016.

NUNES, Eduardo. O povo do rio: variações míticas e variações antropológicas sobre a origem e a diferenciação dos grupos Iny. Revista Tellus, ano 18, n36. 2018. Disponível em http://www.tellus.ucdb.br/index.php/tellus/article/view/489

PAULA, Eunice Dias de. Eventos de fala entre os Apyãwa (Tapirapé) na perspectiva da etnossintaxe: singularidades em textos orais e escritos. Tese (Doutorado em Letras), Universidade Federal de Goiás, Goiânia, 2012.

RODRIGUES, Patrícia Mendonça. A caminhada de Tanyxiwè: uma teoria Javaé da história. Tese (Doutorado em Filosofia) - Departamento de Antropologia da Divisão de Ciências Sociais da Universidade de Chicago. 2008.

SEVERINO-FILHO, João. Marcadores de Tempos Indigenas: a solidariedade entre os povos e o ambiente que habitam. Tese (Doutorado em Educação Matemática) - Instituto 
de Geociências e Ciências Exatas, Universidade Estadual Paulista, Rio Claro -SP. 2015a.

SEVERINO-FILHO, João. A experiência etnográfica: sobre habitar e ser habitado pelo mundo Apyãwa. Boletim de Educação Matemática, vol. 29, n 53, pp. 845-866. 2015 b.

TAPIRAPÉ, Bismarck W. Calendário do povo Apyãwa. Jornal Informativo do Núcleo Takinahaky de Formação Superior de Professores Indígenas Licenciatura Intercultural - UFG. Goiânia, julho, ano I, n 0. 2009a.

TAPIRAPÉ, Gilson Ipaxi'awyga, Yrywaxa Tapirapé, Ikatopawyga Daniela Tapirapé e Koxawiri Tapirapé, Koxawiri Tapirapé, Júlio César Tawy’i Tapirapé, Josimar Ieremy’i Tapirapé, Arapaxigi Tapirapé, Klebson Awararawoo’i Tapirapé, Koxamare’i Tapirapé, Kaxowari’i Tapirapé, Xaripe'i Tapirapé, Mônica Veloso. Histórias Apyãwa. Revista articulando e construindo saberes. v. 2, n. 1. 2017. https://www.revistas.ufg.br/racs TORAL, André. Cosmologia e Sociedade Karajá. Dissertação (Mestrado em Antropologia social). Museu Nacional. Universidade Federal do Rio de Janeiro, Rio de Janeiro. 1992.

REIS, Paula Grazielle Viana dos. O filme Traços Tapirapé: Iraxao e o Antropoceno. In: Conference Proceedings 18th Iuaes World Congress / Anais $18^{\circ}$ Congresso Mundial de Antropologia, GROSSI, Miriam P., SILVA, Simone Lira da [et al] (org.). Florianópolis, Tribo Ilha Editora, (4), p.5038-5053. 2018. Disponível em: https://www.iuaes2018.org/conteudo/view?ID_CONTEUDO $=767$

VIANA DOS REIS, Paula Grazielle. Relatório técnico final: Antropologia compartilhada entre o povo indígena Apyãwa: cinema e etnografia. Relatório de pesquisa: BE-SWP-CNPq. Maio de 2019.

VIANA DOS REIS, Paula Grazielle \& CAIXETA DE QUEIROZ, R. Plano de trabalho Antropologia compartilhada entre os índios Apyãwa (Tapirapé): cinema e etnografia. Supervisão: Alice Fátima Martins (PPGACV-FAV-UFG). Aprovado em Chamada 2018 - BE-SWP-CNPq/ Cronograma 2. 2018. 
VIANA DOS REIS, Paula Grazielle \& MARQUES DAMAS, Vandimar. Ensaio Visual Casas, terreiros e T/terra: fotografias da festa-ritual-sazonal Iraxao. PROA Revista de Antropologia e Arte. n.8, v.2. 2018. Disponível em: https://www.ifch.unicamp.br/ojs/index.php/proa/article/view/3001

VIVEIROS DE CASTRO, Eduardo. Os termos da outra história (comentário sobre as visões indígenas sobre a origem dos brancos). In: RICARDO, Carlos Alberto (org.). Povos Indígenas no Brasil, 1996-2000. São Paulo: Instituto Socioambiental. 2000. p. 49-54.

VIVEIROS DE CASTRO, Eduardo. A propriedade do conceito. In: ANPOCS, 2001. ST 23: Uma notável reviravolta: antropologia (brasileira) e filosofia (indígena), Caxambu, 2001, p. 1-54. Disponível em < https://www.anpocs.com/index.php/encontros/papers/25-encontro-anual-da-anpocs/st4/st23-1/4695-ecastro-a-propriedade/file>. Acesso em: 09, janeiro e 2020.

WAGLEY, Charles. The Charles Wagley Papers Digital Collection. Disponível em: http://ufdc.ufl.edu/dlosawagley

\section{Referências Fílmicas}

Filme etnográfico. CAÇANDO UM ARAPAIMA GIGAS COM UM ARRASTÃO (KARAJÁ). Harald Schultz. Mae-USP. 1960.

Filme etnográfico. CERÂMICA: FAZENDO UMA PANELA PARA COZINHAR (JAVAÉ). Harald Schultz. Mae-USP. 1960.

Filme etnográfico. CROCHETANDO ORNAMENTOS DAS PERNAS (JAVAÉ). Harald Schultz. Mae-USP. 1960.

Filme etnográfico. DANÇA DE MÁSCARAS “ARUANÃ” (JAVAÉ). Harald Schultz. Mae-USP. 1960. 
Filme etnográfico. FAZENDO OS NÓS DE UM ENFEITE DE CABEÇA DE PENAS (KARAJÁ). Harald Schultz. Mae-USP. 1960.

Filme etnográfico. FAZENDO OS NÓS DE UMA ESTEIRA GRANDE (KARAJÁ). Harald Schultz. Mae-USP. 1960.

Filme etnográfico. PESCANDO POR MEIO DO ENVENENAMENTO DA ÁGUA (KARAJÁ). Harald Schultz. Mae-USP. 1960.

Filme etnográfico. SANGRAMENTO POR MEIO DE ARRANHAMENTO DA PELE (JAVAÉ). Harald Schultz. Mae-USP. 1960.

Filme etnográfico. TRABALHANDO UMA CANOA (KARAJÁ). Harald Schultz. Mae-USP. 1960.

Filme etnográfico. TRANÇANDO UMA PEQUENA ESTEIRA COM REBORDO FORTE (JAVAÉ). Harald Schultz. Mae-USP. 1960.

Filme documentário. INY: RITXOKÓ. Direção Manuel Ferreira Lima. UFG - IPHAN. 2011. Acesso: https://youtu.be/E7dcWIiyPUQ

Filme documentário. TRAÇOS TAPIRAPÉ. Direção Vandimar Marques Damas. UFGCapes. 2016b. Acesso: https://vimeo.com/217294858

Filme documentário. VEVA TAPIRAPÉ. Verbo filmes. 2004. Acesso: https://www.youtube.com/watch?v=M2mWTgDVphQ

Vídeo digital. OS MIL NOMES DE GAIA. Isabelle Stengers. Puc Rio/ Museu Nacional-UFRJ-CNPq. 2014-2015. Acesso: https://osmilnomesdegaia.eco.br/ 


\section{Coleções etnográficas e fotográficas}

Coleção Latino-americana Charles Wagley abrigada no site da Universidade da Flórida.

\section{Produção artística}

Alguma cosmopolítica entre os índios Xetá e Tapirapé. Website. 2019. Acesso: https://etnologiaindigena.wordpress.com/2017/01/19/titulo-do-post-do-blog-2/

Recebido: 09/01/2020

Aprovado: 15/07/2020 